\title{
The Market for Corporate Assets: Who Engages in Mergers and Asset Sales and are there Efficiency Gains?
}

\author{
Vojislav Maksimovic Gordon Phillips* \\ Robert H. Smith School of Business \\ University of Maryland \\ First draft: June 14, 1999 \\ Current version: September 20, 1999 \\ Comments Welcome
}

\footnotetext{
*This research was supported by NSF Grant \#SBR-9709427. We wish to thank Sang Nguyen and researchers at the Center for Economic Studies for their comments and help with the data used in this study. Maksimovic can be reached by email at vmax@mbs.umd.edu, Internet homepage: www.mbs.umd.edu/Finance/vmax/. Phillips can be reached by email at GPhillips@mbs.umd.edu, Internet homepage: www.mbs.umd.edu/Finance/gphillips/. The research was conducted at the Center for Economic Studies, U.S. Bureau of the Census, Department of Commerce. The authors alone are responsible for the work and any errors or omissions.
} 


\title{
The Market for Corporate Assets: Who Engages in Mergers and Asset Sales and are there Efficiency Gains?
}

\begin{abstract}
We analyze the market for firms, divisions and plants of manufacturing firms using a large sample of plant-level data for the period 1974-92. There is an active market for corporate assets, with over 7 percent of plants transacted through mergers and asset sales in expansion years in the economy. Transactions through partial firm sales represent more than half of these transactions. The probability of asset sales and full firm transactions is related to firm organization and buyer and seller ex ante productivity. We find that these transactions result in ex post productivity increases especially for asset sales from peripheral divisions of selling firms to main divisions of other buyers. Finally we find that productivity increases are significantly higher the more productive the buying firm.

This timing of sales and the pattern of productivity gains suggests that the transactions that occur, especially through asset sales of plants and divisions, tend to improve the allocation of resources and are consistent with a simple neoclassical model of profit maximizing by firms. The decision to participate in the market for corporate assets and the subsequent gains realized from transactions are affected both by firm productivity and firm organization.
\end{abstract}




\section{The Market for Corporate Assets}

\section{Introduction}

What types of firms engage in mergers, acquisitions and asset sales, and when do the transactions occur? While the literature has succeeded in providing many insights about the gains and losses in mergers, it has provided only a partial picture of the extent of the trade in assets between firms. ${ }^{1}$ Most studies ignore firm organization or are based on agency models. In addition, empirical studies have often focused on mergers and acquisitions by large firms, whereas mergers and acquisitions comprise only a fraction of the total number of asset sales between firms, and do not include trade in individual plants or divisions. ${ }^{2}$ Our study treats mergers, acquisitions and asset sales as components of the overall market for firm assets. ${ }^{3}$ We thus can characterize how this market for corporate assets works, who participates in this market, and most importantly whether this market results in actual productivity changes for the assets being transacted.

In this paper we analyze the market for corporate assets (changes in ownership of plants, divisions, and whole firms) in manufacturing industries. Our principal inquiry centers on whether firm organization affects assets flow to more productive uses. We ask three central questions: What are the industry and firm characteristics that are associated with the probability of an asset or firm sale and purchase? Are transactions associated with productivity gains, and do these gains vary by the buying and selling firm's organizational characteristics? Can the observed transactions be explained by a simple profit-maximizing model of asset adjustment across multiple industries in response to differences in productivity between firms, or is a substantial fraction of transaction explained by agency costs?

Our analysis is motivated by a simple neoclassical model which predicts that firms sell (purchase) assets when they have more (less) valuable growth opportunities elsewhere, and when there is a gain to their redeployment (purchase). We analyze transactions for a sample of plant-level data for over 50,000 manufacturing firms across the business cycle from 1974

\footnotetext{
${ }^{1}$ For a comprehensive survey see Jensen and Ruback (1983) and also Ravenscraft and Scherer (1987).

${ }^{2}$ Ravenscraft and Scherer $(1987,1989)$ and McGuckin and Nguyen (1995) are exceptions. Ravenscraft and Scherer use FTC line-of-business accounting data to examine ex post merger performance of divisions. McGuckin and Nguyen focus on a large sample that contains small and large plants in the food industry that change ownership.

${ }^{3}$ There have been several studies (see Alexander, Benson, and Kampmeyer (1984), Hite, Owers, and Rogers (1987), and Jain (1985), Lang, Poulsen, and Stulz (1995), John and Ofek (1995)) focusing on asset sales. The number of transactions in these studies has been fairly small given the difficulty of getting this type of data.
} 
to 1992. Our data enables us to track sales of individual plants and to benchmark their efficiency against that of other plants in the industry.

The market for individual plants and divisions is extensive, with an average annual rate of reallocation of $3.89 \%$. However, this average masks substantial variation. The overall market is strongly procyclical. In expansion years $6.19 \%$ of manufacturing plants are involved in mergers and acquisitions and asset sales, with asset sales representing $3.47 \%$ percent of these transactions. In recession years these percentages fall to $3.57 \%$ of manufacturing plants, with asset sales representing $1.42 \%$ of these transactions.

We find that the probability that a firm is a buyer of assets increases with its efficiency and size. We identify three distinct subsets of firms: Conglomerate sellers and buyers of individual plants and divisions, single-industry and single-plant firms, and conglomerates that are sold.

The sellers and buyers of individual plants and divisions tend to be large conglomerates. Assets are more likely to be sold when they are less productive than the industry mean, when the selling division is less productive, when the industry is undergoing a positive demand shock, and when the selling firm has more productive divisions in other industries. We find evidence that it is the less productive firms that tend to be sold at times of industry expansion. Buyers are more likely to purchase assets when they are efficient and add to specific industries when that industry is experiencing a positive increase in demand.

A firm's internal organization has a significant effect on the probability that an asset is sold. Assets are significantly more likely to be sold by a peripheral divisions than by main divisions of conglomerates. The sales of main units are much rarer events, perhaps because only divisions in which the firm has a core competence become main divisions. For conglomerates, we also find that the probability of the whole firm being sold off is negatively correlated with firm size and with firm focus.

Our results show that most transactions in the market for assets result in increases in productivity. These increases are particularly striking for transactions involving partial and full divisions, when the buyer is a main division of a conglomerate or a single-segment firm and when the seller is a peripheral unit of a conglomerate. The average productivity of the buyer's and seller's existing assets is an important determinant of the gain to trade, suggesting that firms have differing levels of ability to exploit assets, and that their comparative advantage is in their main industries. ${ }^{4}$ Thus, the market for corporate assets facilitates the redeployment of assets from firms with a lower ability to exploit them to firms with higher

\footnotetext{
${ }^{4}$ Maksimovic and Phillips (1998b) show that conglomerates grow their more productive segments faster.
} 
ability. There is less support for the hypothesis that asset transfers are predominantly driven by agency considerations, such as empire building. However, since measured gains are negative for a minority of transactions we cannot reject the hypothesis some transactions may be motivated by agency considerations.

Single-plant firms form a distinct category of sellers. Unlike divisional and multi-plant transactions, single-plant firms are more likely to be sold the more productive they are and the larger they are. The probability of sale is higher when the industry is experiencing a positive shock, and this timing effect is stronger the higher the firm's productivity. The majority of these firms are purchased by larger multi-division firms and the average gain in productivity under new ownership is lower than that the average gain when partial or full divisions are purchased. This suggests that there is a significant market for higher quality single-plant firms that are purchased by larger firms, but that the purchasers tend not have greater ability to exploit the assets.

In contrast to the firm-level differences, we find only limited evidence that cross-sectional differences in industry characteristics explain the rate of transactions over the whole sample period. The one exception is that the rate of transactions is positively related to the industry's returns to scale. However, we do find a strong economy wide effect. The rates of partial firms sales, as well as mergers and full firm sales, have a strong procyclical effect.

Much of the prior literature on the gains from mergers has examined the gains to the bidders and targets in the stock market. These studies show that the selling firms receive most of the gains in stock market appreciation. Several studies have examined the cash flow performance of firms before or after mergers. Matsusaka (1995) examines the ex ante performance financial performance of firms before they merge and Ravenscraft and Scherer (1987, 1989) examine the ex post financial performance of mergers using FTC line-of-business data. Other studies that have documented performance changes following mergers using the LRD include Lichtenberg and Siegel (1992), McGuckin and Nguyen (1995). Kaplan and Weisbach (1992) track bustups of mergers and find that many of the poorly performing mergers were subsequently busted up. Our approach differs from these studies because we study mergers and firm ownership change as part of a larger set of asset redeployments. Our tests are motivated by the profit-maximizing model of Maksimovic and Phillips (1998b) that predicts which firms add to different business segments. To test these predictions we examine the cross-sectional dispersion in the changes in productivity using detailed plant-level data and find evidence that the changes in productivity vary by firm organization.

Two recent studies by Mitchell and Mulherin (1996) and Andrade and Stafford (1999) argue that industry characteristics such as technological changes and capacity utilization are 
strongly associated with the incidence of mergers, takeovers, and investment. We are able to exploit plant-level data to obtain a more detailed picture of firm-level determinants of asset transactions. Our evidence suggests that firm organization and efficiency drives most of the intra-industry trades.

There is a smaller literature that focuses on specific aspects of asset sales, independent of mergers. Alexander, Benson, and Kampmeyer (1984), Hite, Owers, and Rogers (1987), and Jain (1985) have found a positive stock market response to asset sales. Lang, Poulsen, and Stulz (1995) have shown these asset sales follow poor firm-level performance and that the stock-market gains are positive for firms that payout the proceeds instead of reinvesting within the firm. John and Ofek (1995) show that the remaining assets of the firm improve in performance after asset sales which subsequently leave the firm more focused.

We provide an alternative picture of this market than is found in many studies that focus on agency costs. Following Jensen (1988), many researchers have argued that firms managers' have a tendency to overinvest. Such empire building would suggest that firms may acquire assets which they cannot run efficiently. More recently, several researchers have looked at how organizational structure affects the allocation of resources. Maksimovic and Phillips (1998b) show that the growth by conglomerates' divisions is consistent with a simple profit-maximizing model. Scharfstein and Stein (1998) and Rajan and Zingales (1998) argue that the main divisions subsidize inefficient peripherals. While our evidence does not bear directly on these questions, it does suggest that on average market transactions are not motivated by agency considerations. Transactions are associated with subsequent increases in productivity with assets moving from inefficient firms to efficient ones. ${ }^{5}$

This paper is organized as follows. We discuss our framework of analysis in Section II. The data is discussed in Section III. Section IV presents the descriptive statistics of the market for assets. The firm's decisions to buy and sell and the gains from the transaction are analyzed in Sections V and VI, respectively. Section VII concludes.

\section{Framework for Analysis}

The basic question we examine is simple: Does firm organization affect whether assets flow to more productive uses? The specific hypotheses that we test are motivated by a neoclassical model of firm organization across multiple markets, advanced by Maksimovic and Phillips (1998b). The model shows how a profit-maximizing firm chooses the quantity of

\footnotetext{
${ }^{5}$ However, we do not have data on the prices paid for acquisitions. Thus, we cannot rule out the possibility that agency considerations lead firms to overpay.
} 
capacity to employ in each industry and how demand shocks in one industry, in which the firm operates, affect its capacity decisions in other industries. It provides predictions on how firm organization affects who trades assets, and the magnitude of the gains from trade. These predictions differ from the predictions of models that assume that firms acquire assets outside their main industry because managers engage in empire building behavior. Thus, the predictions of the model can be used to test the hypothesis that the trade in assets by multi-industry firms allocates assets to more productive uses. This section describes the model and gives the empirical tests motivated by the model.

\section{A. Industry Fundamentals and The Market for Assets}

Our analysis is based on a model of profit maximizing firms in Maksimovic and Phillips (1998b). Following Lucas (1978), they argue that management teams of firms differ in their ability to operate plants efficiently. ${ }^{6}$ Given that it is more difficult to manage a large firm than a small firm, firm size, and the scope of a firm's operations adjust to economize on the abilities of managers. As industry conditions change, assets are traded until the gain from operating the marginal plant is equalized across all firms in the industry.

Profit maximizing firms trade assets when there are gains to trade. Gains exist when the buyer can use the asset more productively than the seller. Thus, in the absence of market imperfections or empire building by managers, assets are predicted to flow from less efficient divisions or firms to more efficient divisions or firms. ${ }^{7}$ (In this section and in the empirical work, efficiency refers to productive efficiency or the ability to produce more output with a given level of inputs.) Both the probability that an asset is sold, and the expected gain in productivity, are negatively related to the efficiency of the selling division or firm, and positively related to the efficiency of the buying firm.

The model predicts that the purchases and sales of assets will be procyclical. The reason more assets are purchased during booms is that buyers face increasing costs of supervision and management as the firm gets bigger (decreasing returns to scale). Thus, gains on the purchase of an asset have to be larger as the firm purchases more assets. In boom times, the value of increased production is higher thus compensating firms for their increasing costs of managing a larger firm. Conversely, the cost of assets being run by inefficient firms and

\footnotetext{
${ }^{6}$ More generally, their model can be reinterpreted as positing the existence of a fixed firm-specific factor of production that induced diminishing returns-to-scale. Following Lucas (1978) they identify this factor with managerial or more generally organizational ability. A formal derivation is given in Maksimovic and Phillips (1998b).

${ }^{7}$ This holds under the maintained hypothesis that there are significant differences in skill levels at the level of the firm. See Schmalensee (1986) for a contrary view.
} 
managers is higher in boom times as the value of that capacity, operated efficiently, is higher.

These predictions regarding the flow of assets between firms have implications for the analysis of firm organization and restructuring. Profit maximizing firms grow more in industries in which they have a comparative advantage. Thus, on average the larger divisions of multi-segment firms are predicted to have a higher mean productivity than smaller, peripheral divisions. ${ }^{8}$ More specifically, the probability that a plant is sold is higher when the plant is in a peripheral division of a multi-segment firm than when the plant is in a main division. On average, the expected gain in efficiency is higher when the plant is sold by a peripheral division and purchased by the buyer's main division, then when it is purchased another peripheral division.

The model also makes predictions about the sale of whole firms. Because firms expand until the marginal product of capacity equals its cost, firm size is correlated with managerial ability. Thus, the model predicts that gains from trade in plants or entire divisions are more likely to arise when the seller has a smaller division in the relevant industry than the buyer. For the same reason, larger firms take over smaller firms.

These predictions do not arise because some types of firm organization are create perverse incentives for managers. Rather, the model predicts systematic differences in productivity between firms of different sizes and main and peripheral units of multi-segment firms. As a result of these systematic differences in productivity across firms' divisions, the probability of buying and selling assets, and changes in the traded assets' productivity, are likely to depend on whether the transactions occur in a main or a peripheral division.

The Maksimovic and Phillips (1998b) model also makes predictions about how demand shocks in the industry affect trade in assets. They focus on the case where firms differ in the quantity of output that they obtain from a given quantity of inputs. As demand increases, output prices also increase and the ability to produce more output becomes relatively more valuable. As a result, the firms managed by able managers gain in size relative to firms managed by less able managers. Thus, the model predicts asset sales from less productive and smaller firms to more productive, and larger, firms when demand increases. The volume of sales is higher when the technology in the industry is such that productivity does not decrease steeply as a firm acquires more capacity in the industry. The magnitude of transactions in response to such demand shocks depend, in part, on whether or not there are significant diseconomies of scale.

Similar trade-offs between managerial ability and size apply to multi-segment firms. A

\footnotetext{
${ }^{8}$ Maksimovic and Phillips (1998b) examine this prediction and show it to be consistent with plant-level census data.
} 
firm grows its segments until the value of a marginal investment is equalized across industries in which it operates. Thus, a firm's operations in one industry may affect its decision to buy or sell plans in another industry. The model predicts that a firm reduces its capacity in an industry by selling assets when the value of these assets to another firm is higher. The opportunity cost may be high either because other firms in the industry can better use the assets, or because the firm has better prospects in other industries. ${ }^{9}$ Thus, a multi-segment firm sell plants in a segment when its other segments are growing fast and it is an efficient producer in these other segments. It may also sell a segment when the segment is not an efficient producer, but the industry is doing well and the plant is relatively more valuable to other, more efficient, producers.

The purchase decision works similarly. Efficient producers in an industry buy additional plants when the demand level is high because when the output price is high, so is the gain in efficiency when the plant is transferred outweighs the extra costs of operating a large firm. Firms may also purchase plants in an industry when their prospects elsewhere diminish. This occurs if they are efficient producers in other industries and these industries suffer negative demand shocks. It may also occur if they are inefficient producers in other industries who sell out to more efficient producers when the other industries receive a positive price shock.

To summarize, the profit-maximizing model suggest tests of the following conjectures:

Conjecture 1 Sales of assets are associated with increases in productivity of the traded assets. The highest gains will occur when assets are sold by peripheral units and purchased by the main units of firms. Such transactions are more likely to occur when the industry receives a positive demand shock.

The above predictions do not depend on the existence of agency conflicts or financial market imperfections. This contrasts with several alternative theories that posit that certain firm characteristics are associated with perverse expansion and takeovers. To the extent that such transactions are motivated by opportunistic behavior of managers, they are not likely to be associated with increases in productivity. ${ }^{10}$

The value of marginal differences in managerial ability changes with industry demand. As a result, it becomes profitable to reallocate capacity when demand increases.

\footnotetext{
${ }^{9}$ Firms may also scrap assets if the demand in the industry is sufficiently low.

${ }^{10}$ It is possible that opportunistic managers correctly identify approprate transactions, and then sustematically overpay to acquire them. Our analysis would not pick up this type of imperfection.
} 
Conjecture 2 When the main division of a multi-segment firm receives a positive demand shock, the firm will sell capacity in the peripheral divisions. When the main unit receives a negative demand shock, the firm will acquire assets in peripheral units.

This prediction comes directly from the model in Maksimovic and Phillips (1998b). We would also expect to see similar effects when peripheral units receive demand shocks. However, these are less likely to be detectable because peripheral units are smaller. This conjecture differs from Jensen's (1988) claim that when firms have excess cash flow, they tend to use it to acquire additional assets outside their area of competence.

Conjecture 3 The observed association between organizational structure and transactions can be explained by differences in productivity between different types of units. In particular, the neoclassical model predicts that sales in multi-segment firms follow a specific pattern: when the industries in which other segments operate are doing well, and the other segments are productive, there is an increased probability that the segment is sold. When other segments are doing badly, and this other segments are also relatively less productive, there is also a higher probability that the the segment will be sold.

This prediction may also be used to distinguish the neoclassical model from the agency models of multi-segment firms. Work motivated by models of market imperfection, such as Lamont (1996) suggests that firms would be more likely to purchase assets outside their main divisions when their main division receives a positive demand shock. Thus, the prediction on the effect of demand shocks on the purchase and sale decisions in other industries is opposite that of our model.

The neoclassical model does not make a distinct predictions for transactions involving the whole firm - such as mergers - and transactions involving only some plants or divisions. However, mergers of multi-divisional firms may involve the transfer of some divisions that do not fit under new ownership and that would not have occurred in isolation. Thus, we would expect the neoclassical model to fit the data when individual transactions are considered better than in the case of mergers.

To the extent that the significant agency conflicts in the firm are between the managers and investors, agency models would suggest that efficiency enhancing whole firm transactions are more likely to be blocked by incumbent target managers than similar partial firm transactions. Thus, only the mergers which promise the greatest increases in productivity would occur. Thus, the existence of such agency conflicts in target firms would induce a sample selection, so that the observed mergers would appear to lead to greater gains than 
observed partial firm transactions. This greater efficiency gain would be greatest in the case of the main divisions of target firms, since a bidder is more likely to take over a target in order to acquire a main division than a peripheral.

Jensen's (1988) agency model also suggests several testable hypotheses that are not suggested by the neoclassical model. These hypotheses all stem from the Jensen's central intuition that when firms have excess cash flow, they may use it to acquire additional assets outside their area of competence. Thus, we would expect to observe segment acquisitions by cash rich firms, and firms in industries where investment needs are low. We develop four predictions from agency models that we will test:

1.) The probability of a purchase depends on buyer's cash flow independent of other factors (productivity, demand and returns to scale.

2.) Buyers in low growth industry tries to move into high growth especially when the buyer has high cash flow.

3.) The increase in productivity of acquired assets is lower when the buyer is a high cash flow firm - especially when the purchase is outside of their industry.

Another model that has implications for the timing of asset sales is Shleifer and Vishny (1992). Shleifer and Vishny stress the importance of asset sales that occur when industries become temporarily distressed. They argue that firms that distressed firms are forced to sell assets to industry outsiders. Since outsiders are less skilled in running the assets than industry insiders, such transactions create a value loss. Firms adjust their financial structures to equalize the marginal loss from such distressed sales to the gains of increased leverage. The magnitude of observed productivity changes for transactions which occur in recessions depends on the extent to which firms adopt conservative financial structures so as to avoid such transactions. However, unless firms are able to avoid completely such transactions, their model predicts that transactions in which plants are sold in recessions are more likely to result in productivity decreases. This is particularly true when the buyer is not an industry insider.

Thus their model predicts that in recessionary times the assets sold by firms with high debt that are sold outside of the industry will result in productivity declines. Given the model assumes that the best firms are operating the assets initially, assets sold inside the industry will experience either no change or a slight decrease in productivity. The model also predicts that purchasers from inside the industry will have low debt. 


\section{Data and Variable Selection}

\section{A. Data}

We examine both multiple-segment conglomerate firms and single-segment firms by using an unbalanced panel for the period 1975 to 1992. To be in our sample, firms must have manufacturing operations producing products in SIC codes 2000-3999. We require firms to meet these criteria because of the unique nature of the micro-level data that we use to calculate plant-level productivity and industry-segment growth.

We use data from the Longitudinal Research Database (LRD), maintained by the Center for Economic Studies at the Bureau of the Census. ${ }^{11}$ The LRD database contains detailed plant-level data on the value of shipments produced by each plant, investments broken down by equipment and buildings, and the number of employees. The LRD tracks approximately 50,000 manufacturing plants every year in the Annual Survey of Manufactures (ASM). The ASM covers all plants with more than 250 employees. Smaller plants are randomly selected every fifth year to complete a rotating five-year panel.

There are several advantages to this database: First, it covers both public and private firms in manufacturing industries. Second, coverage is at the plant level, and output is assigned by plants at the four-digit SIC code level. Thus, firms that produce under multiple SIC codes are not assigned to just one industry. Third, plant-level coverage means that we can track plants even as they change owners. In addition to a plant-level identifier the database contains a code that identifies which assets change ownership. These two features are key to our study as we identify assets that have changed hands from year-to-year. Thus, plants have to be part of an ASM panel for the plants to remain in our study.

We confine our analysis to 1974 through 1992. We use 1974 as the starting year of our analysis because it is the first year of a five-year panel; 1992 is the last year of data available to us. We aggregate our data into firm business-segment units at the three-digit SIC code from the individual plant-level data. We exclude segments that are less than $\$ 1$ million in real value of shipments, and segments which have continuously compounded annual growth rates greater than $500 \%$ in absolute value.

We classify firms as single segment or multiple segment based on three-digit SIC codes. If a firm produces $97.5 \%$ of its sales or higher in one three-digit SIC code, we classify that firm as a single-segment firm and exclude the small peripheral segment. We classify all other firms are multiple-segment firms. For these firms, we also classify each segment as either

\footnotetext{
${ }^{11}$ For a more detailed description of the Longitudinal Research Database (LRD) see McGuckin and Pascoe (1988)
} 
a main segment or a peripheral segment. Main segments are segments whose real value of shipments (in 1982 dollars) is at least $25 \%$ of the firm's total shipments.

\section{B. Transaction Types}

We classify asset transactions into several categories. Firms can purchase or sell one or more plants, entire divisions, or a whole firms. ${ }^{12}$ Acquisitions can be in industries in which the firm already operates, or in new industries. While any of the transaction motives discussed above may apply in every category, their importance may differ because transactions in each category have different implications for the exploitation of future growth opportunities, and for corporate control.

In our paper we classify transactions into three types: single plant transactions by single-plant firms, multi-plant transactions broken into full divisions and partial divisions, and full firm transactions. We break transactions into these three categories as we it seems plausible that transactions in which a single plant changes hands between multi-plant firms in the same industry are marginal investment transactions that have the least implications for both future investment policy and corporate control. Transactions in which a division is sold, or a division is acquired in a new industry have greater implications for both. Finally full firm transactions are ones in which it is likely that the managerial incentives are quite different given that the assets involve a full change in control.

\section{Variable Selection}

In this section we describe the variables used to test our model and how we calculate the fundamental industry and segment-level variables used in our tests. Specifically, we use segment productivity, calculated industry returns-to-scale, business cycle indicators and the change in aggregate industry shipments to test the predictions of our propositions.

\section{C1. Productivity of Business Segments}

We calculate productivity for all firm segments at the plant level. Our primary measure of performance is total factor productivity (TFP). TFP takes the actual amount of output produced for a given amount of inputs and compares it to a predicted amount of output. "Predicted output" is what the plant should have produced, given the amount of inputs it used. A plant that produces more than the predicted amount of output has a greater-thanaverage productivity. This measure is more flexible than the cash flow measure, and does not impose the restrictions of constant returns to scale and constant elasticity of scale that a "dollar in, dollar out" cash flow measure requires.

In calculating the predicted output of each plant, we assume that for each industry there

\footnotetext{
${ }^{12}$ These categories may overlap, as in the case of a the purchase of a single-plant firm.
} 
exists a production function that defines the relation between a plant's inputs and outputs. Then, for each industry we estimate this production function using an unbalanced panel with plant-level firm-specific fixed effects, using all plants in the industry within our 1974 to 1992 time frame.

We assume that the plants in each industry have a translog production function. This functional form is a second-degree approximation to any arbitrary production function, and therefore takes into account interactions between inputs. To estimate predicted outputs, we take the translog production function and run a regression of $\log$ of the total value of shipments on the log of inputs, including cross-product and squared terms:

$$
\ln Q_{i t}=A+\sum_{j=1}^{N} a_{j} \ln L_{j i t}+\sum_{j=1}^{N} \sum_{k=j}^{N} a_{j k} \ln L_{j i t} \ln L_{k i t}
$$

where $Q_{i t}$ represents output of plant $i$ in year $t$, and $L_{j i t}$ is the quantity of input $j$ used in production for plant $i$ for time period $t$. Ais a technology shift parameter, assumed to be constant by industry, and $a_{j}=\sum_{i=1}^{N} a_{j i}$ indexes returns to scale. We also include a plant-level fixed effect. Plants that change ownership have a different fixed effect for each owner, allowing the plant-level unmeasurable effects to differ by owner.

Our measure of TFP is the residual from equation (1) plus the plant-level firm-specific fixed effect. We include the fixed effect to capture persistent firm-specific skill at the plant level. We also used as our measure of TFP just the residual from equation (1), as this is the more traditional measure of productivity. The results using this measure of productivity were the qualitatively and statistically similar to the results presented that include the fixed effect. We standardize plant-level TFP by dividing by the standard deviation of TFP for each industry. Thus, our comparisons of plants' TFP are not driven by differences in the dispersion of productivity within each industry.

In estimating the TFPs in our sample, we use data for over 500,000 plant years, and for approximately 50,000 plants each year. In the productivity regression for each industry, we include three different types of inputs, capital, labor, and materials, as explanatory variables. All these data exist at the plant level. However, the ASM does not state the actual quantity shipped by each plant, but shows only the value of shipments. As a result, we take the difference between actual and predicted value of shipments as our measure of TFP. We adjust for inflation by using four-digit SIC code data from the Bartelsman and Gray (1994) database. We use data from the Bureau of Economic Analysis to make depreciation adjustments at the two-digit level. To capture vintage effects of capital, we include plant age in our productivity calculations. Plant age is the first year in which the plant appeared in the 
database, or 1972 (the first year of the database) whichever is earlier. Kovenock and Phillips (1997) describe these inputs and the method for accounting for inflation and depreciation of capital stock in more detail.

To measure the productivity for a firm's entire business segment, we construct a weighted average of individual plant productivity, in which the weights are the plant-level value of shipments. The variable for the productivity of the firm's other segments is the weighted average of all of the firm's other plants outside of the segment in question. Again, the weights are the plant-level value of shipments.

We also include other firm and segment-level variables in our regressions to provide additional control for unmeasured productivity differences and other factors, such as size, that can influence firm growth. We include the log of firm size and the number of plants operated by a firm at the beginning of the year. We define firm size as the total value of shipments.

\section{C2. Industry Variables: Returns to Scale, Industry Shipments and Business-Cycle Classifications}

The primary variable we focus on as a proxy for the gain to redeploying an asset is the annual growth in the real value of total industry shipments. We focus on shipment growth for two reasons. First, the value of capital and of allocating resources to growth in an industry depends on industry growth. Second, firms' cash constraints can depend on industry conditions. If firms in high-growth industries are less cash-constrained than those in declining industries, then firms might have different growth rates. For industry shipments, we use the Bartelsman and Gray (1994) database at the three-digit SIC code level.

The second industry variable we include in our analysis is industry returns-to-scale. Industry returns-to-scale influences the value of allocating resources to a specific industry. We calculate several different measures of industry demand and supply conditions. Our central variables are industry-level return-to-scale, the yearly and long-run changes in industry shipments, and capacity utilization.

We calculate industry returns-to-scale, $\lambda$, by estimating a system of equations derived by assuming cost minimization for a given production function. The system consists of a translog production function and additional input demand equations. We estimate the translog production function simultaneously with input demand equations, equating input factor shares to the first-order conditions from the production function and imposing homogeneity of degree $\lambda$.

Using aggregate industrial production data, we also classify years as recession or expansion years. We determine recession and expansion years by using aggregate and aggregate- 
detrended industrial production. We define detrended industrial production as the actual less predicted industrial production, where we calculate predicted industrial production from a regression of industrial production on a time trend. Recession years are years in which both real and detrended industrial production decline relative to the previous year. We classify years as expansion years when both real and detrended industrial production increase relative to the previous year.

This procedure gives us similar results as the NBER recession dating procedure, which NBER does quarterly. It also allows us to classify a year such as 1980, which, according to NBER, had a recession of less than six months. Using this procedure, we classify 1981-1982 and 1991 as recession years. For comparability we also take the top 3 expansion years 1986-1988. (Other expansion years were 1976-1978 and 1984-1985). Given that actual and detrended industrial production did not move in the same direction, 1979-1980, 1983, 1989, 1992 are indeterminate years

\section{The Basic Facts}

\section{A. The Number and Timing of Transactions}

Table I presents summary statistics for asset reallocations in our dataset between 1974 and 1992. We break out the transactions into whole firm dispositions (mergers and takeovers) and sales of assets by firms that remain in existence. ${ }^{13}$ We consider two types of asset sales by firms that remain in existence: whole division sales when a firm divests itself of all operations in an industry (defined at the 3-digit SIC code level), and partial division sales where a firm sells only some of its plants in an industry.

\section{Insert Table I here}

Table I shows that from 1974 to 1992, the total number of plants reallocated in mergers and takeovers was approximately equal to the total number of plants reallocated in sales by ongoing firms. On average $1.95 \%$ plants are reallocated annually through takeovers and mergers, whereas $0.95 \%$ and $0.99 \%$ are reallocated through sales of entire and partial divisions respectively. In each case the plants reallocated tend to be below average in size for their industry. More plants than not are sold to buyers whose major focus is producing in the same

\footnotetext{
${ }^{13}$ Thus, a firm that sells its only division is classified as a merger.
} 
industry, defined at the 3-digit SIC code level. ${ }^{14}$ The proportion of same industry buyers is lowest for whole firm dispositions, and highest for partial division sales. Table I also shows that more transactions occur in industries which are in expansion than in recession.

Table I also shows the 2-digit SIC code industries with the highest and lowest rates of reallocations in our sample. The highest annual rate is $4.72 \%$, for Rubber and Plastics, followed by Electronics, Primary Metal products, Optical Equipment and Processed Food Products. The lowest annual reallocation rate is $2.77 \%$, for Leather and Leather Products, followed by Clothes and Apparel, Printing and Publishing, Lumber and Wood products and Oil Refining. Comparing the types of transactions across industries, it is evident that the rates of partial and full-division sales in particular differ considerably across these industries. Thus, for example, the full division sales rates for Rubber and Plastics and Leather and Leather Products are $1.33 \%$ and $0.68 \%$ respectively. The corresponding rates for partial division sales are $1.36 \%$ and $0.46 \%$ respectively.

Table II explores several potential industry and economy-wide determinants of the rates of asset reallocations. More asset are reallocated in expansions. The rates of reallocations during expansion years (the three years with the highest increases in the aggregate real value of industries production) and recession years (the three years with the largest decline in the aggregate real value of industries production) are $6.20 \%$ and $3.57 \%$, respectively. The rates of full- and partial-division sales, in particular, are much higher in expansions $(1.73 \%$ and $1.78 \%$, respectively), than in recession years $(0.170 \%$ and $0.72 \%$, respectively). The reallocations rate due to mergers is somewhat higher in expansions than in recessions $(2.69 \%$ compared to $2.16 \%$ ). By contrast, the total reallocation rate in the remaining "indeterminate" years is $3.21 \%$, the reallocation rate due to mergers is a low $1.73 \%$, whereas the partial- and full-division sales rates are $0.78 \%$ and $0.70 \%$ respectively. Thus, the partialand full-division sales are highest in expansion years.

\section{Insert Table II here}

Table II also shows how the rate of reallocations varies with industry returns-to-scale. The rates at which transactions take place are uniformly higher in industries which are in the top quartile when ranked by returns-to-scale than in industries which are in the bottom quartile.

\footnotetext{
${ }^{14}$ More precisely, buyers for whom that industry is one of the top two industries in which they operate, and who produce at least $25 \%$ of their output in that industry.
} 
We next explore differences in capacity utilization on the rate of transactions. For each year we use capacity utilization to classify into quartiles all the 3-digit SIC industries. We report the average rate of transactions over the sample period for the top and bottom quartile. As Table II shows, the rates of reallocation do not differ materially across capacity utilization quartiles.

We also report the rates of reallocations by long-run industry growth. As Table II shows, more reallocations take place in the fastest growing industries - 15,746 in the fastest growing quartile compared to 6,290 in the slowest growing quartile of industries. However, the overall rate of transactions is similar at approximately $4 \%$. There is some limited evidence that industries which have more moderate growth rates have a somewhat lower rate of transactions, but the effect, if it exists, is relatively small.

We also subclassify the reallocations into those that occurred in years in which the industry (at the 3-digit SIC level) was in expansion, and those that occurred in years in which the industry was in recession. For an industry to be classified as being in expansion, its real production in that year has to increase and its real level of output has to exceed its long-term trend level. For an industry to be classified as being in recession, the industry's real output has to decline in that year and the real level of output has to be below the long-term trend level.

Table II suggests that the average rate of reallocations, and in particular the rate of partial firm sales, is higher in periods of macroeconomic expansion. There is less evidence that differences in industry conditions have a material effect.

A similar pattern emerges when the time-series of sales is plotted. Figure I shows the annual rate of reallocations.

\section{Insert Figure I here}

Figure I shows that Consistent with Table II, the annual percentage of plants is high in expansions. It is highest in 1986 and in 1987, when nearly 7\% of the plants change ownership (adding up mergers and full and partial firm asset sales). The proportion of transactions that occur in industries that are in expansion also varies considerably, and procyclically. In 1987 and 1988 when few industries are in recession, the number of plants transacted in these industries clearly declines.

However, when we plot the time-series of the proportion of plants transacted in industries that were in recession and expansion in Figure 2, we find that the proportions are very 
similar. The reason for this result is that few industries are in recession in when the overall economy is in expansion. Those that are in recession have a similar proportion of plants transacted. Thus, time-series variation in the rate of asset reallocations is driven by economy-wide factors.

\section{Insert Figure II here}

We next examine the time-series variation in the percentage of plants transferred by mergers and takeovers, division sales and partial-division sales. Figure III breaks the transactions into mergers and full firms sales, full segment sales, and partial segment sales. In particular, mergers are strongly procyclical, rising in the years before the 1982 recession to over $3 \%$ of assets, before falling to $1 \%$ of assets in 1984 . The rate of merges increased again to almost $4 \%$ of assets by 1987 . Partial firm asset sales vary less year by year however they still hit a peak of over 4\% (combining full and partial segment sales) in 1987.

\section{Insert Figure III here}

The summary statistics suggest that the rate of plan sales, and in particular of fulland partial-divisions sales, is affected by economy-wide factors. There is less evidence that the average rate of transactions is affected by industry factors, such as capacity utilization and long-term growth. We next explore how within industry and within firm characteristics affect the sale of plants.

\section{B. Who are the Buyers and Sellers?}

Table III shows the characteristics of the firms which sell and acquire assets, by categories of transaction. In the table we also break down mergers into those which involve sellers with just one plant, sellers in just one industry, and sellers who operate in more than one industry. In all cases the characteristics are measured in the year prior to the transaction. The acquiring firm in the case of partial and full divisional sales, is the buying firm. In the case of mergers and takeovers these are the surviving firms. For mergers we also report the characteristics of buyers who operate in multiple 3-digit SIC code industries. 


\section{Insert Table III here}

Firms that sell full- and partial divisions tend to be quite large (average revenues of $\$ 1.328$ and $\$ 1.849$ billions respectively) and operate in an average of approximately eight 3-digit industries. Sellers of partial divisions tend to operate a greater number of plants (an average of 31.48 in contrast to an average of 23.72 plants operated by sellers of entire divisions). Only approximately a quarter of the plants sold in the sales of entire divisions belonged to one of the seller's main divisions, whereas approximately half of plants sold in partial division sales belonged to one of the seller's main divisions.

Buyers of entire divisions are of similar size and operate a similar number of plants as the sellers, whereas the buyers of partial divisions are on average about two thirds as large as the sellers. Both categories of buyer tend to be slightly more focused than the sellers, operating in an average of approximately six 3-digit SIC code industries. The buyers' main divisions acquired $53.8 \%$ and $63.1 \%$ of the plants purchased in entire- and partial-division transactions, respectively. Thus, market for asset sales is one in which both the buyers and sellers are conglomerate firms. The sellers sell peripheral divisions and marginal plants to the main divisions of the buyers. While the buyers are somewhat smaller and more focused than the sellers, the differences between them are not large.

In contrast, the average seller in a merger operates 1.78 plants and has sales of $\$ 51 \mathrm{~m}$. Approximately eighty percent of all full firm sales (mergers and purchases) involve the sale of small, one-plant firms. About ten percent of all mergers involve multi-plant single-industry firms (average number of plants 5.15) and approximately ten percent involve multiple industry firms. Even in this last category the sellers have an average of only seven plants, sales of $\$ 239 \mathrm{~m}$ and operate in an average of approximately three 3-digit SIC code industries. Buyers of whole firms are larger than the sellers. On average they operate 16.64 plants, produce in 4.66 3-digit SIC code industries, and have annual sales of $\$ 856 \mathrm{~m}$. About a half of the acquired plants are operated by the buying firms's main divisions.

There are several differences between the buyers in partial firm dispositions and mergers. On average buyers of full or partial divisions tend to be larger then buyers in mergers, they operate more plants, and to operate in a larger number of industries. These differences arise because a larger proportion of buyers in mergers are single-industry firms. The subset of buyers in mergers who operate in multiple industries are slightly bigger in size and in the number of industries in which they operate. 


\section{The Probability of a Sale:}

\section{C.1 How Sales vary with Firm Organization}

In this section investigate how firm productivity and firm organization influences the probability of a sale. Before running statistical tests and examining the impact of productivity, we first present two simple figures which show how internal firm segment rank is associated with different frequencies of sales.

Figure IV examines partial firm asset sales. It shows the proportion of assets sold by division rank. As the segment rank of a particular segment increases, the proportion of assets sold for firms with that number of segments increases sharply. The largest segment of a firm is the least likely to be sold versus smaller segments for multiple-segment firms. The proportion of firms selling their largest segment is less than $1 \%$ for firms with seven or more segments, while the proportion of firms who sell their smallest segments rises to 3 and $4 \%$.

\section{Insert Figure IV here}

Figure $\mathrm{V}$ examines how the probability of a full-firm sale or merger increases with the number of firm segments a firm operates. This graph shows that as the number of segments a firm operates in increases the proportion of firms merged with that number of segments decreases sharply. Single-segment firms are the most likely to be bought out or merged.

\section{Insert Figure V here}

\section{C.2 Seller Characteristics and the Probability of a Sale}

In Table IV we analyze how seller characteristics and firm organization influences partial firm sales. We separately examine sellers who are single-segment firms, and multiple-segment firms. We break down multi-divisional firms into main (greater than $25 \%$ of sales) and peripheral divisions (all other divisions). To qualify for the subsample of firms that might have a partial firm sale, the single-segment firms have at least two plants.

\section{Insert Table IV here}


We expect a multiple-segment firm's decision to sell plants or an entire segment to be influenced by its performance in other segments. We test for this effect, allowing the influence to be different for main and peripheral divisions. ${ }^{15}$ In each case we run a unbalanced panel probit regression allowing for correlated residuals within panel units, and we report heteroskedasticity consistent standard errors.

Regardless of the seller's classification, the probability that a plant is sold is inversely related to its productivity. The probability of a sale is also higher when the plant is in an industry where decreasing returns to scale are less severe. In the case of partial segment sales, the probability of a sale is higher when the segment's productivity is lower than the industry average. ${ }^{16}$ Thus, the behavior of sellers is consistent with the hypothesis that they are selling plants which they do not have a superior expertise in running, and that such sales are more likely to occur in industries the transaction does not negatively affect the productivity of potential buyers' existing assets.

For single-segment firms, the probability that an inefficient (less productive) plant is sold is higher when the industry experiences a positive change in shipments. This is consistent with Maksimovic and Phillips' (1998b) neoclassical model of firm growth, which predicts that asset sales from less productive sellers to more productive buyers are more likely occur when demand increases.

Industry changes in aggregate shipments affect the probability of a partial sale of plants in main and peripheral divisions differently. The probability that a sale of a peripheral plant occurs is higher when the industry has a positive shock, whereas the probability of main division sale is not affected. For both peripheral and main divisions, the probability of a sale declines as the plant and firm productivity increases. This is consistent with the firm selling its worst divisions and plants. In addition, the sign of the coefficient of segment productivity interacted with industry shock is negative for all divisions and for the main and peripheral divisions. This is consistent with firms selling their worst plants and divisions in expansionary times.

For all multi-segment firms, the probability of a plant sale is higher if the firm's other segments are productive. This effect is stronger for peripherals than for main divisions. In

\footnotetext{
15 In unreported regressions we also analyze partial segment and full segment sales separately. In all material respects the results are qualitatively similar. In addition we analyzed alternative specifications in which the firm multiple segment variables were weighed by the size of eash segment. The results do not differ in any material respect.

${ }^{16}$ In unreported regressions we also examine the choice of which plant to sell within a segment. The probability that a plant is sold is negatively related to the difference between its profitability and that of the other plants in the segment.
} 
addition, the probability that a main division of a multi-segment firm is sold is higher when the firm's other segments are productive and the firm's other industries are expanding fast. The probability of sale is also positively and significantly related to the segment's rank within the firm: the probability that a plant in a smaller segment is sold is higher, holding industry shocks and productivity constant.

In sum, the results in Table IV are consistent with profit maximizing behavior by sellers. Plants are more likely to be sold when they are not productive, when their segment is less productive, and when the firm has better performing assets elsewhere.

In Table $\mathrm{V}$ we analyze mergers and whole firm selloffs. As before, we split the sample of selling firms into single-segment and multiple-segment firms. Since the majority of selling firms are small single-plant firms, we also analyze these separately.

\section{Insert Table V here}

In all cases the probability that a whole firm is sold is lower in industries with high decreasing returns to scale. Thus, firm sales are more probable in industries where the purchase of additional assets by other firms does not have an adverse effect on a potential buyer's existing assets.

In contrast to the case of partial firm sales, the role of fundamental productivity variables in predicting mergers is less clear-cut. The probability that a single-plant firm is sold increases with the firm's productivity. However, there is no relation between productivity and whole firm sales of multiple-plant and multiple-segment firms. Moreover, the probability that a productive single-plant firm is taken over is higher when the industry experiences a positive shock. The reverse is true for multiple-plant firms: the probability that a productive multiple-plant firm is sold is lower when the industry experiences a positive shock. The the behavior of full-firm sales of multiple-plant firms is consistent with our model. The behavior of single-plant firms is not consistent with our model. It is consistent with the previous results found by McGuckin and Nguyen (1995).

The relation between firm size and the probability of sale also differs across the categories in Table $\mathrm{V}$. There is a positive relation between firm size and the probability of sale, no relation for multiple-plant-single-segment firms, and negative relation for multiple-segment

firms. For multiple-segment firms, diversification is positively related to probability of selling the firm. However, firms with a high average number of plants per industry have a higher probability of sale. 
In sum, firm sales are more probable in industries with low decreasing returns to scale and low sensitivity to aggregate industrial fluctuations. At the firm level there are distinct segments in the market for whole firms. Productive, single-plant firms are more likely to be sold, particularly when industry shipments are increasing. The probability of sale of multiple-segment firms is not affected by their productivity or by the changes in industry demand. However, when demand falls, inefficient multiple-segment firms are more likely to be sold than productive single-segment firms.

\section{C.2 Buyer Characteristics and the Probability of a Sale}

In Table VI we examine the buyers of whole firms. We consider single-segment and multi-segment firms separately. To investigate whether the motives for focus-increasing and diversifying purchases are the same, we classify multi-segment buyers into those for whom the purchase increases firm focus and those for whom it decreases focus, as measured by the firms' Herfindahl index.

\section{Insert Table VI here}

In all cases, even for diversifying firms, the probability that a firm is a buyer in a particular industry increases with the buying firm's segment TFP and size. For all classifications, except single-segment firms with multiple plants, the probability of being a buyer also increases as the firm's weighted average returns-to-scale increases. For multi-plant firms, the probability also increases with the number of plants the firm already owns. These results indicate that firms are growing in industries in which they are productive and which the diseconomies associated with size are smaller.

The effect of changes in industry demand on the probability of being a purchaser differ across firm categories. The coefficient on the change is industry shipments in the regressions for single-segment firms is positive, although it is significant only for the case of single-plant firms.

To investigate whether the predictors of focus-increasing and diversifying purchases are the same, we classify multi-segment buyers into buyers whose purchase is in one of their top three industries versus buyers whose purchases are outside of their main divisions. Conglomerates more likely to purchase other firms when demand in the industry is decreasing. This result is consistent with the Maksimovic and Phillips (1998b) model in which firms become more focused in expansions and more diversified in recessions. 
We also regressed (but do not report) firm productivity (TFP) on the number of peripherals and the number of peripherals squared. Consistent with the model which predicts more segments for firms who can transfer ability across industries, and predicts that decreasing returns to moving across industries would mitigate this effect, we found that the firm TFP was positively related to the number of peripherals but negatively related to the number of peripherals squared.

\section{Are there gains and what determines the gains?}

In this section we examine the productivity change surrounding the asset sales - both for full firm mergers and sales and for partial firm sales. To begin the analysis we first present simple summary statistics on the change in productivity for the manufacturing plants involved in purchases subsequent to the transactions.

Table VII presents the industry adjusted change in productivity from the year before the transaction to two years after the transaction, year -1 to year +2 , where year 0 is the year of the transaction. We present the changes using a two-by-two matrix to capture both the buying and selling firm internal organization characteristics.

\section{Insert Table VII here}

Panel A of Table VII presents the change in productivity for partial firm asset sales by multi-divisional and single-segment firms. This distinction makes a difference. We find that all sales from peripheral divisions have significant ex post changes in productivity, regardless of the buyer organizational characteristics. For sales from main divisions of multi-segment firms, only transactions for buyers that add to their main division result in increases in productivity. For single-segment sellers, no transactions resulted in a significant increase in productivity.

Panel B presents the change in productivity for full firm sales and mergers. Two facts emerge: First we find productivity gains only when buyers add capacity to their main divisions - increasing the focus of their firm. Second, single-segment buyers are not very successful. These transactions (although not very frequent) result in productivity decreases for the purchasing firm. Thus we there is evidence that restructuring that involves sales from multi-segment firms to single-segment firms does not result in gains. 
We next investigate the multivariate determinants of these changes in productivity. We run regressions of the change in productivity (industry adjusted) for all plants and also conditional on a transaction. We split the analysis into buyers and sellers as for the plants not involved in transactions the independent variables would be the same.

Table VIII presents the multivariate analysis explaining the change in productivity using selling firms characteristics. Column 1 uses OLS while column 2 includes firm-level fixed effects. Column 3 analyzes the change in industry-adjusted productivity for just the plants that were sold. We include both transaction-characteristic dummy variables and firm-specific variables.

\section{Insert Table VIII here}

The results in columns 1 and 2 show that the productivity gains are primarily for asset sales for partial or full divisional asset sales and especially so when the asset sale is in a peripheral division (given that the main division dummy variable is significantly negative). These gains are over-and-above the gains that accrue to other industry firms with similar size, number of industries, and similar firm organization (multiple divisional and main division dummy variables for all firms).

The results in column 3 conditional on a sale occurring show again that gains are primarily for asset sales of peripheral divisions of multi-segment firms. The results for mergers and full firm sales are significantly lower. (These productivity gains are still positive as the constant is a significant .141). Finally the results show that the productivity gains are significantly larger when the selling firms productivity ex ante productivity is lower.

Table IX gives the economic significance of these results. In Table IX we present the

predicted change in plant-level productivity for the asset transacted, varying seller initial productivity from the 25 th to the 75 th percentiles. We hold all other variables at their sample medians. We use the coefficient estimates from Table VIII, column 3.

\section{Insert Table IX here}

Table IX shows that the change in productivity responds significantly to seller initial productivity. The worse off in ex ante productivity the firm selling the assets is, the larger 
the ex post productivity gain for the assets transacted. There is a large effect on the change in TFP that is driven by who is involved in the transaction.

These results (Table VIII and IX) combined with the summary statistics which show significant increases in productivity are consistent with the market for assets working well. Assets that are transacted result in significant gains especially for partial firm sales and assets in peripheral divisions. Contrary to hypothesis that these divisions get subsidized by their parent firms, multi-divisional firms are more likely to sell less productive divisions and these sales to other firms that result in subsequent productivity increases. These results are consistent with the market for assets is working well. Our results support the conclusion that assets change hands as the prospects in their other industries improve and the owner finds out that they do not have a comparative advantage in running these assets.

Table $\mathrm{X}$ presents the multivariate analysis explaining the change in productivity using the buying firm's characteristics. Column 1 uses OLS while column 2 includes firm-level fixed effects. Column 3 analyzes the change in industry-adjusted productivity for just the plants that were purchased. We include both transaction-characteristic dummy variables and firm-specific variables.

\section{Insert Table X here}

The results in columns 1 and 2 show that the productivity gains are result for partial or full divisional asset sales and especially so when the asset purchase is in the same industry as a buyer's main division. We also find that buyers in mergers have significant gains when the purchase is part of the buying firms main division. This result adds additional evidence to the analysis of selling firm characteristics as we did not find significant gains (over no transaction) occurring for mergers. These gains are over-and-above the gains that accrue to other industry firms with similar size, number of industries, and similar firm organization (multiple divisional and main division dummy variables for all firms).

The results in column 3 conditional on a purchase occurring show again gains accrue to asset sales and to full firm purchases when that purchase is in the buyer's main division. The results also show that the more productive the buyer is, the larger the gain in productivity for the purchased asset. This result is very interesting and striking because it potentially justifies the stock market premium that is paid to sellers of assets. Firms are able to offer a premium in part because of the gains in real productivity that occur. The result is 
consistent with more skilled buying firms being able to transfer skill and improve the assets they purchase.

Table XI gives the economic significance of these results. In Table XI we present the predicted change in plant-level productivity for the assets transacted, varying buyer initial productivity from the 25 th to the 75 th percentiles. We hold all other variables at their sample medians. We use the coefficient estimates from Table X, column 3.

\section{Insert Table XI here}

Table XI shows that the change in productivity responds significantly to the buying firm's initial productivity. The better off in ex ante productivity the firm buying the assets is, the larger the ex post productivity gain for the assets transacted.

Overall these results show that there are significant gains for assets being redeployed from less productive sellers to productive buyers. The results are consistent with the simple neoclassical model of Maksimovic and Phillips (1998b) which predicts that more productive firms will expand their operations in good times and when their prospects in a given industry look better than their other industries in which their operate.

\section{Conclusions}

In this paper we analyze the market for corporate assets (plants, divisions and whole firms) in manufacturing industries. We analyze both the buyers and sellers of corporate assets. We show that the market for both full and partial firms is extensive. We have four main results on the probability an asset is reallocated to another firm:

1. For multiple division firms the probability of a firm selling assets decreases with its productivity.

2. In contrast, the probability of a sale of a single segment firm increases with its productivity. Better small firms get bought out.

3. The selling firm's productivity in other divisions impacts the probability of a sale. The better the prospects of the other divisions, the more likely the current division is to be sold. 
4. We find that the probability that a firm is a buyer of additional assets increases with its efficiency and size. For mergers and full-firm purchases, the distinction between focusincreasing transactions and focus-decreasing purchases is important. Focus-decreasing purchases are more likely when industries decline, while focus-increasing purchases are more likely when industry cash flow increases.

In addition, we show that ex post productivity changes occur for assets transacted and these productivity changes are associated with buyer and seller initial productivity and firm organization. We find the following results documenting that real changes in productivity occur for assets involved in these transactions:

1. The gain in productivity of assets under new ownership is higher when the selling firm's productivity is low and is higher the more productive the buyer.

2. A firm's internal organization is also associated with observed changes in productivity of the asset sold. Assets added to main divisions of buyers and from peripheral divisions of sellers have significant productivity gains.

We thus show that firm organization matters both in the determining who trades in the market for assets and also in the ex post productivity gains observed after the transactions. The productivity gains we document are consistent with buying firms able to offer a premium in part because of the gains in real productivity that occur. The result is consistent with more skilled buying firms being able to transfer skill and improve the assets they purchase.

This timing of sales and the pattern of productivity gains suggests that the transactions that occur in the market for plants and divisions tend to improve the allocation of resources and are consistent with profit maximizing by firms across the divisions they operate. Taken together, our results suggest that most transactions in the market for assets result in an increase in efficiency. The increase is particularly striking for transactions involving partial and full divisions, when the buyer is a main division of a conglomerate or a single-segment firm and when the seller is a peripheral unit of a conglomerate. The average productivity of the buyer's and seller's existing assets is an important determinant of the gain to trade, suggesting that firms have differing levels of ability to exploit assets, and that their comparative advantage is in their main industries. Both the decision to participate in the market for corporate assets and the subsequent gains realized from transactions are affected by firm productivity and organization. We conclude that the market for corporate assets facilitates the redeployment of assets from firms with a lower ability to exploit them to firms with higher ability. 


\section{REFERENCES}

Alexander, G. J., P. Benson, and J. Kampmeyer, 1984, Investigating the Valuation Effects of Announcements of voluntary Corporate Selloffs, Journal of Finance, 39, 503-17.

Andrade, Gregor and Erik Stafford, Investigating the Economic Role of Mergers, working paper, Harvard Business School.

Bartelsman. Eric J. and Wayne Gray, 1994, The NBER Manufacturing Productivity Database.

Berger, Philip G. and Eli Ofek, 1997, Causes and Effects of Corporate Refocusing Programs, Journal of Finance.

Cabellero, Ricardo J., Eduardo M.R.A. Engel, and John C. Haltiwanger, 1995, Plant level adjustment and aggregate investment dynamics, working paper, University of Maryland.

Caves, Richard E. and David R. Barton, 1991, Efficiency in U.S. Manufacturing (MIT Press, Cambridge, MA).

Coase, Ronald, 1937, The nature of the firm, Economica 4, 386-405

Gertner, Robert H., David S. Scharfstein, Jeremy Stein, 1994, Internal versus External Capital Markets, Quarterly Journal of Economics, 109(4), 1211-30.

Hite, G.L., J.E. Owers, and R.C. Rogers, 1987, The Market for Interfirm Asset Sales: Partial Sell-offs and Total Liquidations, Journal of Financial Economics, 18, 229-52.

Jain, P., 1985, The effect of Voluntary Sell-offs Announcements on Shareholder Wealth, The Journal of Finance, 40, 209-224.

Jensen, Michael C., 1986, Agency costs of free cash flow, corporate finance, and takeovers, American Economic Review 76, 323-329.

John, K. and E. Ofek, 1995, Asset Sales and the Increase in Focus, Journal of Financial Economics 37, 105-126.

Kaplan, Steven N. and Michael Weisbach, 1992, The Success of Acquisitions: Evidence from Divestitures, The Journal of Finance, 47, 107-138

Kovenock, Daniel, and Gordon Phillips,1997, Capital structure and product market behavior: An examination of plant exit and investment behavior, Review of Financial Studies 10, 767-804.

Lang, Larry, Annette Poulsen and Rene Stulz, 1995, Asset Sales, Firm Performance, and the Agency Costs of Managerial Discretion, Journal of Financial Economics 37, 3-38.

Lichtenberg, Frank, R., 1992, Industrial De-diversification and Its Consequences for Productivity, Journal of Economic Behavior and Organization; 18(3), 427-38.

Lichtenberg, Frank R. and Donald Siegel, 1992, Takeovers and corporate overhead, In Corporate Takeovers and Productivity, Frank R. Lichtenberg ed., MIT Press, Cambridge, MA.

Lucas, Robert, 1978, On the size distribution of business firms, Bell Journal of Economics $9,508-23$. 
McGuckin, Robert H. and Sang V. Nguyen, 1995, On Productivity and Plant Ownership Change: New Evidence from the LRD, RAND Journal of Economics.

McGuckin, Robert, Sang Nguyen and Arnold Reznek, 1995, The Impact of Ownership Change on Employment, Wages, and Labor Productivity, Center for Economic Studies working paper, \#95-8.

McGuckin, Robert H., and George Pascoe, 1988, The longitudinal research database: status and research possibilities, Survey of Current Business. 68, 30-37.

Maksimovic, Vojislav, and Gordon Phillips, 1998a, Asset Efficiency and Reallocation Decisions of Bankrupt Firms, Journal of Finance, 53, 1619-43.

—, 1998b, Do Conglomerate Firms Allocate Resources Efficiently, Center for Economic Studies working paper, 1998-2.

Maksimovic, Vojislav, and Josef Zechner, 1991, Debt, agency costs, and industry equilibrium, Journal of Finance 46, 1619-43.

Matsusaka, John G, 1993, Takeover motives during the conglomerate merger wave, Rand Journal of Economics 24, 357-43.

Mitchell, Mark L., and Harold J. Mulherin, 1996, The Impact of Industry Shocks on Takeover and Restructuring Activity, Journal of Financial Economics; 41:2, 193-229

Morck, Randall, Shleifer, Andrei and Robert W. Vishny, 1989, Alternative mechanisms for corporate control, American Economic Review 79, 842-52.

Peters, Thomas and Robert Waterman, Jr, 1982, In Search of Excellence: Lessons from America's Best-Run Companies, Warner Books, New York.

Rajan, Raghuram G., Henri Servaes and Luigi Zingales, 1997, The Cost of Diversity: The Diversification Discount and Inefficient Investment, working paper.

Ravenscraft, David and F. M. Scherer, 1987, Mergers, Sell-Offs, and Economic Efficiency. Brookings Institution, Washington.

—, 1989, The profitability of mergers, International Journal of Industrial Organization, 7 , 101-116.

Scharfstein, David S., 1997, The Dark Side of Internal Capital Markets II, mimeo, MIT.

Scharfstein, David S. and Jeremy Stein, 1997, The Dark Side of Internal Capital Markets: Divisional Rent Seeking and Inefficient Investments, mimeo, MIT.

Shleifer, Andrei, and Robert W. Vishny, 1992, Liquidation values and debt capacity: A market equilibrium approach, Journal of Finance 47, 1343-1365.

Stein, Jeremy, 1997, Internal Capital Markets and the Competition for Corporate Resources, Journal of Finance 52, 111-33. 
Table 1

Asset Reallocations: Summary Statistics

Sample characteristics for asset reallocations for the years 1974-1992. Reallocations include partial firm asset sales and sales through takeovers and mergers in which the selling firm disposes of all its assets. Plant-level data is obtained from the Annual Survey of Manufactures (ASM) from the Bureau of the Census, U.S. Department of Commerce. The average annual percentage of plants reallocated is the number of plants reallocated in a given year divided by the total plants, averaged over all years. The percentage sold to buyer inside industry excludes plant sales to buyers with no existing plants in manufacturing prior to the purchase. Average plant sizes are the total value of shipments for each plant deflated by three-digit SIC code deflators from the Bureau of Economic Analysis.

Sample of Firms

Total Mergers Asset Sales and Takeovers Full Division Partial Division

\section{Full Period: 1974-1992}

Number of plants reallocated

Average Annual \% of Plants Reallocated

$\%$ Plants sold to buyer inside industry*

- same 3 digit SIC code

- same 4 digit SIC code

Average Plant Size (Real \$ Value of Shipments)

Average Industry Plant Size

$\begin{array}{cccc}35,291 & 17,720 & 8,556 & 9,015 \\ 3.89 \% & 1.95 \% & 0.95 \% & 0.99 \% \\ 56.8 \% & 54.1 \% & 55.5 \% & \\ 47.7 \% & 44.9 \% & 47.9 \% & 63.1 \% \\ \$ 30,332 & \$ 28,435 & \$ 30,916 & \$ 33.0 \% \\ \$ 35,790 & \$ 34,569 & \$ 36,440 & \$ 37,574\end{array}$

\section{$\underline{\text { Reallocation rates by } 2 \text {-digit SIC code }}$}

Industry reallocations: Highest quartile

SIC Code: 30, Rubber and Plastic Products

Yearly percentage plant sales (number of sales)

SIC Code: 36, Electronics / Communications

Yearly percentage plant sales (number of sales)

SIC Code: 33, Primary Metal Products

Yearly percentage plant sales (number of sales)

$4.61 \%(3037)$

$2.12 \%(1397)$

$1.28 \%(840)$

$1.21 \%(800)$

SIC Code: 38, Scientific / Optical Equipment

Yearly percentage plant sales (number of sales)

$4.49 \%(1663)$

$1.95 \%(732)$

$1.33 \%(487)$

$1.20 \%(444)$

SIC Code: 20, Processed Food Products

Yearly percentage plant sales (number of sales)

$4.38 \%(1113)$

$2.22 \%(570)$

$1.32 \%(332)$

$0.83 \%(211)$

$4.24 \%(2358)$

$2.23 \%(2358)$

$0.58 \%(603)$

$1.40 \%(1491)$

Industry reallocations: Lowest quartile

SIC Code: 29, Oil refining

Yearly percentage plant sales (number of sales)

$3.21 \%(307)$

$2.13 \%(307)$

$0.51 \%(71)$

$0.58 \%(82)$

SIC Code: 24, Lumber and wood products

Yearly percentage plant sales (number of sales)

$3.04 \%(1436)$

$1.54 \%(743)$

$0.59 \%(273)$

$0.90 \%(420)$

SIC Code: 27, Printing and publishing

Yearly percentage plant sales (number of sales)

$2.99 \%(1104)$

$1.84 \%(1104)$

$0.57 \%(331)$

$0.57 \%(344)$

SIC Code: 23, Clothes and apparel

Yearly percentage plant sales (number of sales)

$2.95 \%(1495)$

$1.78 \%(893)$

$0.55 \%(275)$

$0.62 \%(327)$

SIC Code: 31, Leather and leather products

Yearly percentage plant sales (number of sales)

$2.77 \%(253)$

$1.63 \%(143)$

$0.68 \%(63)$

$0.46 \%(47)$ 
Table 2

Asset Reallocations: Summary Statistics

Sample characteristics for asset reallocations for the years 1974-1992. Reallocations include partial firm asset sales and sales through takeovers and mergers in which the selling firm disposes of all its assets. Plant-level data is obtained from the Annual Survey of Manufactures (ASM) from the Bureau of the Census, U.S. Department of Commerce. Recession (expansion) years are the three years classified as having the largest decline (expansion) in the aggregate real value of industrial production. Industry returns-to-scale are calculated by the authors for each industry over the period using a translog production function. Industry capacity utilization quartiles are yearly quartiles based on the rates reported by the Department of the Census. Long-run industry growth/decline quartiles are calculated using growth rates for aggregate industry shipments over a fifteen-year period, with beginning and ending periods representing three-year averages for 1974-1976 and 1990-1992.

\section{Sample of Firms}

Total Mergers Asset Sales

and Takeovers Full Division Partial Division

\section{Transactions by aggregate economy conditions}

Recession years $(1981,1982,1991)$

Average \% Reallocated (total number)

Expansion years $(1986,1987,1988)$

Average \% Reallocated (total number)

Indeterminate Years

Transactions by industry returns-to-scale

Low industry returns-to-scale (bottom quartile) Average \% Reallocated (total number)

High industry returns-to-scale (top quartile) Average \% Reallocated (total number)

Transactions by industry capacity utilization

Low industry capacity utilization (bottom quartile)

Average \% Reallocated (total number)

High industry capacity utilization (top quartile) Average \% Reallocated (total number)

\section{Transactions by long-run industry growth/decline}

Quartile 1: Declining industry growth

Average \% Reallocated (total number)

\section{Quartile 2}

Average \% Reallocated (total number)

\section{Quartile 3}

Average \% Reallocated (total number)

Quartile 4: High Industry Growth

Average \% Reallocated (total number)

$\begin{array}{cccc}3.57 \%(5,148) & 2.16 \%(3,112) & 0.70 \%(1003) & 0.72 \%(1033) \\ 6.19 \%(8,989) & 2.69 \%(3,904) & 1.73 \%(2,509) & 1.77 \%(2,576) \\ 3.21 \% & 1.73 \% & 0.70 \% & 0.78 \%\end{array}$

$3.43 \%(12,167) \quad 1.85 \%(6,494) \quad 0.71 \%(2,510) \quad 0.90 \%(3,163)$

$4.13 \%(4,109) \quad 2.11 \%(2,104) \quad 0.98 \%(980) \quad 1.03 \%(1,025)$

$3.86 \%(8,618) \quad 1.90 \%(4,244) \quad 0.99 \%(2,210) \quad 0.97 \%(2,164)$

$3.69 \%(8,413) \quad 1.92 \%(4,375) \quad 0.87 \%(1,977) \quad 0.90 \%(2,061)$

$\begin{array}{llll}4.01 \%(6,290) & 1.95 \%(3,058) & 1.09 \%(1,707) & 0.97 \%(1,525) \\ 3.86 \%(5,250) & 1.96 \%(2,666) & 1.05 \%(1,425) & 0.85 \%(1,160) \\ 3.52 \%(10,008) & 1.80 \%(5,131) & 0.88 \%(2,505) & 0.83 \%(2,372) \\ & & & \\ 4.03 \%(15,746) & 2.01 \%(7,870) & 0.87 \%(3,405) & 1.14 \%(4,471)\end{array}$


Table 3

\section{Buyer and Seller Characteristics}

Sample characteristics of purchasing firms prior to asset purchases for the years 1974-1992. Data is aggregated to firm-level from indidual manufacturing plants. Plant-level data is from the Annual Survey of Manufactures (ASM) from the Bureau of the Census, U.S. Department of Commerce. Buyers without any prior manufacturing plants (foreign buyers, outside manufacturing buyers) are excluded as pre-purchase characteristics can not be calculated. Average buyer and seller size is the average value of total shipments deflated by industry price deflators from the Bureau of Economic Analysis. 1992 was the last year available at the time the study was conducted.

Sample of Firms

\begin{tabular}{|c|c|c|c|c|c|}
\hline & \multicolumn{2}{|c|}{$\underline{\text { Asset Sales }}$} & \multicolumn{3}{|c|}{ Mergers and Takovers } \\
\hline & Full Division & Partial Division & All Plants & $\begin{array}{c}\text { Buyer with } \\
\text { Plants }>1\end{array}$ & $\begin{array}{c}\text { Multiple Industry } \\
\text { Firms (3 digit SIC code) }\end{array}$ \\
\hline \multicolumn{6}{|l|}{ Seller Characteristics Prior to Sale } \\
\hline \multicolumn{6}{|l|}{ Full Period: 1974-1992 } \\
\hline Number of Selling Firms & 3,774 & 4,205 & 11,684 & 2,204 & 1,224 \\
\hline Average Number of Plants & 23.72 & 31.48 & 1.78 & 5.15 & 7.0 \\
\hline Average Seller Size & 1,328 & 1,849 & 51 & 176 & 239 \\
\hline Average Number of 3 digit Industries & 7.56 & 7.77 & 1.22 & 2.21 & 3.17 \\
\hline Average Number of 4 digit Industries & 9.58 & 10.56 & 1.29 & 2.53 & 3.61 \\
\hline \multicolumn{6}{|c|}{$\%$ of plants sold by seller in its primary line of business } \\
\hline - seller's primary 3 digit line(s) $*$ & $28.2 \%$ & $50.8 \%$ & $82.9 \%$ & $70.6 \%$ & $62.2 \%$ \\
\hline - seller's primary 4 digit line(s) $*$ & $25.6 \%$ & $36.3 \%$ & $76.5 \%$ & $61.6 \%$ & $54.9 \%$ \\
\hline \multicolumn{6}{|l|}{ Buyer Characteristics Prior to Purchase } \\
\hline \multicolumn{6}{|l|}{ Full Period: 1974-1992 } \\
\hline Number of Buyers & 2,267 & 2,755 & 6,178 & 4,530 & 3,627 \\
\hline Average Number of Plants & 23.50 & 23.38 & 16.64 & 22.33 & 26.80 \\
\hline Average Buyer Size & 1,307 & 1,357 & 856 & 1,157 & 1,410 \\
\hline Average Number of 3 digit Industries & 6.24 & 5.75 & 4.66 & 6.00 & 7.24 \\
\hline Average Number of 4 digit Industries & 8.21 & 7.58 & 6.04 & 7.87 & 9.51 \\
\hline \multicolumn{6}{|c|}{$\%$ Plants sold to Buyers from Inside Industry } \\
\hline - at the 3 digit SIC code & $53.8 \%$ & $63.1 \%$ & $53.0 \%$ & $30.8 \%$ & $26.3 \%$ \\
\hline - at the 4 digit SIC code & $47.9 \%$ & $55.2 \%$ & $44.9 \%$ & $21.0 \%$ & $17.4 \%$ \\
\hline
\end{tabular}

\footnotetext{
* If the seller (buyer) produces in mutilple industries, the seller's (buyer's) home industries are its which have at least $20 \%$ of the firm's sales.
} 


\section{Table IV}

\section{Partial Firm Sales}

Regressions test the effects of plant-level productivity and industry-level demand on the decision to buy out another firm for single-segment and multiple-segment firms. The dependent variable is a binary variable which indicates that the firm sells a plant, while still remaining in operation the next year. Observations are at the plant level for all firms. Productivity variables are industry and year-adjusted. Segment variables are aggregated into three-digit SIC codes for industry segments from underlying plant-level data. We estimate the regressions using unbalanced panel probit regressions allowing for correlated residuals within panel units. Significance tests are conducted using heteroskedasticity consistent standard errors. Data are yearly from 1975 to 1992. (p-values are in parentheses.)

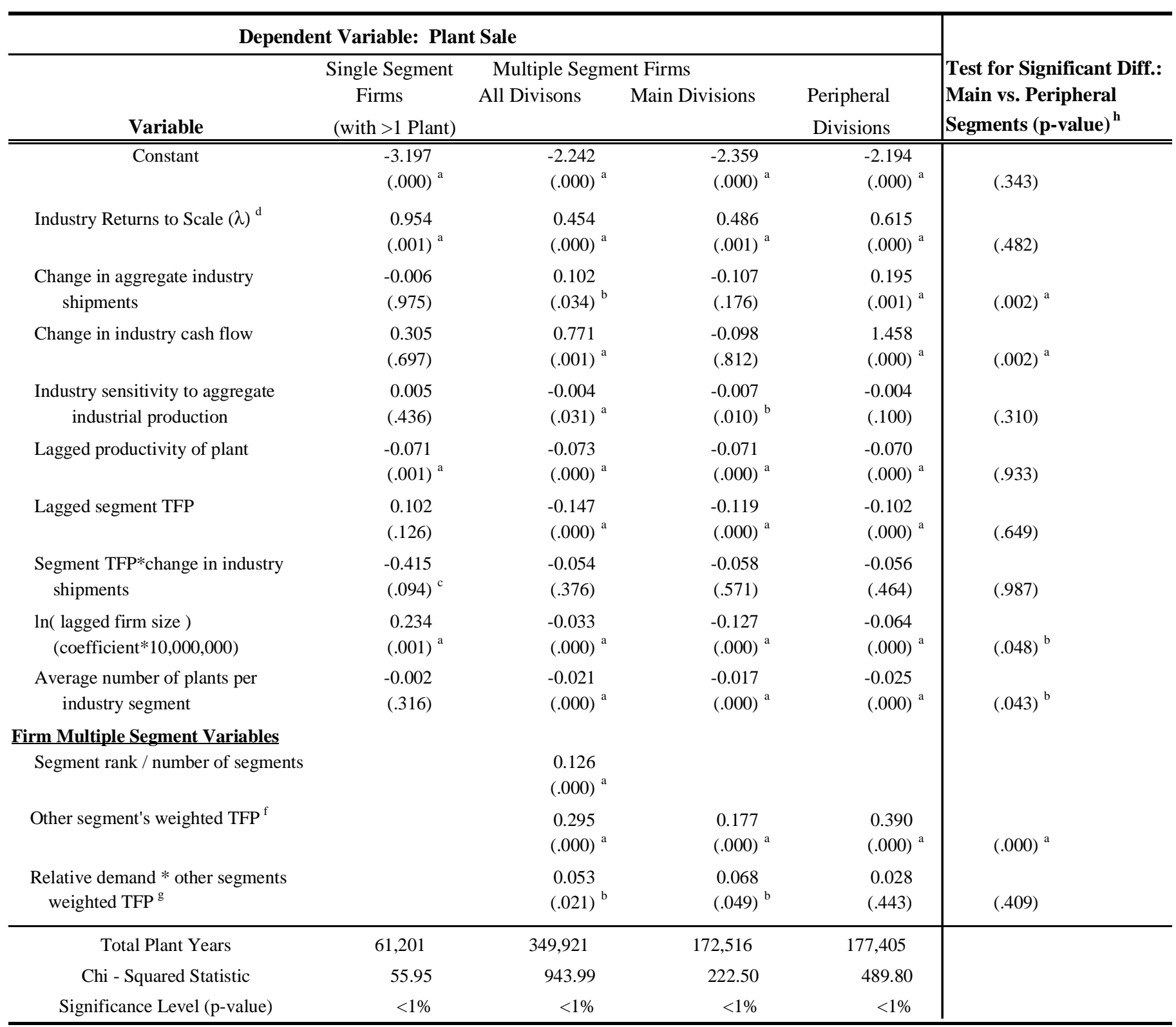

a, b, c : Significantly different from 0 at the $1 \%, 5 \%$, and $10 \%$ levels, respectively, using a 2-tailed test.

${ }^{\mathrm{d}}$ Returns to scale, $\lambda$, is calculated at the three-digit industry segment level by imposing homogeneity of degree $\lambda$ to input

demand equations when estimating a translog production function.

${ }^{\mathrm{e}}$ Total Factor Productivity (TFP) is calculated using a translog production function.

${ }^{\mathrm{f}}$ Other segments' productivity is weighted average of the firm's other segment(s) weighted by the segment(s) sales.

${ }^{\mathrm{g}}$ Relative industry demand is interacted with other segments' productivity and equals one (zero, minus one) when the segment's cash flow at the industry level is greater (equal, less) than that of the firm's median segment.

${ }^{\mathrm{h}}$ Signficance test for a main-segment dummy variable interacted with each independent variable in a regression with all conglomerate firms. 


\section{Table V}

\section{Mergers and Firm Selloffs: Selling Firm Charactistics}

Regressions test the effects of plant-level productivity and industry-level demand on the decision to sell out or merge with another firm for single-segment and multiple-segment firms. The dependent variable is a binary variable which indicates that the firm sells to another firm. Productivity variables are industry and year-adjusted. Firm-level variables are aggregated from plant-level data by weighting each plant by its real value of plant shipments. Industry-level variables are constructured for each firm using as weights the real value of that firm's industry production. We estimate the regressions using unbalanced panel probit regressions allowing for correlated residuals within panel units. Significance tests are conducted using heteroskedasticity-consistent standard errors following Huber-White. Data are yearly from 1974 to 1992. (p-values are in parentheses.)

\begin{tabular}{|c|c|c|c|c|}
\hline \multicolumn{4}{|c|}{ Dependent Variable: Firm Selloff } & \multirow{2}{*}{$\begin{array}{l}\text { Test for Significant Diff.: } \\
\text { Multiple Segment Interaction } \\
\text { Variable (p-value) }\end{array}$} \\
\hline Variable & $\begin{array}{r}\text { Single Segment } \\
\text { Firms with 1 Plant }\end{array}$ & $\begin{array}{r}\text { Single Segment } \\
\text { Firms with }>1 \text { Plant }\end{array}$ & $\begin{array}{r}\text { Multiple } \\
\text { Segment Firms }\end{array}$ & \\
\hline Constant & $\begin{array}{l}0.393 \\
(.080)^{\mathrm{c}}\end{array}$ & $\begin{array}{l}-3.066 \\
(.000)^{\mathrm{a}}\end{array}$ & $\begin{array}{l}-2.597 \\
(.000)^{\mathrm{a}}\end{array}$ & $(.101)$ \\
\hline Industry Returns to Scale $(\lambda)^{d}$ & $\begin{array}{l}1.333 \\
(.000)^{\mathrm{a}}\end{array}$ & $\begin{array}{l}1.320 \\
(.000)^{\mathrm{a}}\end{array}$ & $\begin{array}{l}0.993 \\
(.000)^{\mathrm{a}}\end{array}$ & $(.026)^{\mathrm{b}}$ \\
\hline $\begin{array}{l}\text { Change in aggregate industry } \\
\text { shipments }\end{array}$ & $\begin{array}{r}-0.044 \\
(.507)\end{array}$ & $\begin{array}{l}0.576 \\
(.012)^{b}\end{array}$ & $\begin{array}{l}0.067 \\
(.653)\end{array}$ & $(.047)^{\mathrm{b}}$ \\
\hline Change in industry cash flow & $\begin{array}{l}0.668 \\
(.023)^{b}\end{array}$ & $\begin{array}{l}0.896 \\
(.323)\end{array}$ & $\begin{array}{l}0.475 \\
(.531)\end{array}$ & $(.617)$ \\
\hline $\begin{array}{l}\text { Industry sensitivity to aggregate } \\
\text { industrial production }\end{array}$ & $\begin{array}{l}-0.012 \\
(.000)^{\mathrm{a}}\end{array}$ & $\begin{array}{l}-0.013 \\
(.071)^{\mathrm{c}}\end{array}$ & $\begin{array}{r}-0.005 \\
(.435)\end{array}$ & $(.701)$ \\
\hline Lagged productivity of firm (TFP) & $\begin{array}{l}0.057 \\
(.000)^{\mathrm{a}}\end{array}$ & $\begin{array}{l}0.014 \\
(.636)\end{array}$ & $\begin{array}{r}-0.008 \\
(.743)\end{array}$ & $(.618)$ \\
\hline $\begin{array}{c}\text { Firm TFP*change in industry } \\
\text { shipments }\end{array}$ & $\begin{array}{l}0.219 \\
(.008)^{\mathrm{a}}\end{array}$ & $\begin{array}{l}-0.847 \\
(.015)^{b}\end{array}$ & $\begin{array}{l}-0.512 \\
(.041)^{b}\end{array}$ & $(.459)$ \\
\hline $\begin{array}{l}\ln (\text { lagged firm size }) \\
\quad(\text { coefficient*10,000,000) }\end{array}$ & $\begin{array}{l}7.300 \\
(.001)^{\mathrm{a}}\end{array}$ & $\begin{array}{l}0.241 \\
(.347)\end{array}$ & $\begin{array}{l}-0.187 \\
(.023)^{\mathrm{a}}\end{array}$ & $(.080)^{\mathrm{c}}$ \\
\hline Dispersion (herfandahl) across industries & & & $\begin{array}{l}-0.219 \\
(.000)^{\mathrm{a}}\end{array}$ & \\
\hline Total Firm Years & 95,916 & 24,772 & 42,524 & \\
\hline Chi - Squared Statistic & 870.21 & 160.03 & 253.10 & \\
\hline Significance Level (p-value) & $<1 \%$ & $<1 \%$ & $<1 \%$ & \\
\hline
\end{tabular}

a, b, c : Significantly different from 0 at the $1 \%, 5 \%$, and $10 \%$ levels, respectively, using a 2-tailed test.

${ }^{\mathrm{d}}$ Returns to scale, $\lambda$, is calculated at the three-digit industry segment level by imposing homogeneity of degree $\lambda$ to input demand equations when estimating a translog production function.

e Total Factor Productivity (TFP) is calculated using a translog production function.

${ }^{\mathrm{f}}$ Signficance test for a multiple-segment dummy variable interacted with each independent variable in a regression with all firms with $>1$ plant. 


\section{Table VI}

\section{Mergers and Firm Selloffs: Buying Firm Charactistics}

Regressions test the effects of plant-level productivity and industry-level demand on the decision to buy out another firm for single-segment and multiple-segment firms. The dependent variable is a binary variable which indicates that the firm buys another firm. Observations are at the firm level for all firms. Productivity variables are industry and year adjusted. Segment-level variables are aggregated from plant-level data by weighting each plant by its real value of plant shipments. Industry-level variables are constructured for each firm using as weights the real value of a firm's industry production. We estimate the regressions using unbalanced panel probit regressions allowing for correlated residuals within panel units. Focus-increasing (decreasing) purchases are transactions which result in the buying firm's sum of squared industy market shares (herfandahl) increasing (decreasing). Significance tests are conducted using heteroskedasticityconsistent standard errors following Huber-White. Data are yearly from 1974 to 1992 . (p-values are in parentheses.)

\begin{tabular}{|c|c|c|c|c|}
\hline \multicolumn{5}{|c|}{ Dependent Variable: Firm Purchase } \\
\hline \multirow[b]{3}{*}{ Variable } & \multicolumn{4}{|c|}{ Multiple Segment Firms } \\
\hline & \multicolumn{2}{|c|}{ Single Segment Firms } & \multirow{2}{*}{$\begin{array}{l}\text { Focus-Increasing } \\
\text { Purchase }\end{array}$} & \multirow{2}{*}{$\begin{array}{l}\text { Focus-Decreasing } \\
\text { Purchase }\end{array}$} \\
\hline & With 1 Plant & With $>1$ Plant & & \\
\hline Constant & $\begin{array}{l}-3.200 \\
(.000)^{\mathrm{a}}\end{array}$ & $\begin{array}{l}-1.752 \\
(.000)^{\mathrm{a}}\end{array}$ & $\begin{array}{l}-2.679 \\
(.000)^{\mathrm{a}}\end{array}$ & $\begin{array}{l}-2.382 \\
(.000)^{\mathrm{a}}\end{array}$ \\
\hline Industry Returns to Scale $(\lambda)^{d}$ & $\begin{array}{l}0.709 \\
(.032)^{\mathrm{a}}\end{array}$ & $\begin{array}{r}-0.344 \\
(.365)\end{array}$ & $\begin{array}{l}0.573 \\
(.065)^{\mathrm{c}}\end{array}$ & $\begin{array}{l}0.488 \\
(.090)^{\mathrm{c}}\end{array}$ \\
\hline $\begin{array}{l}\text { Change in aggregate industry } \\
\text { shipments }\end{array}$ & $\begin{array}{l}0.544 \\
(.019)^{\mathrm{c}}\end{array}$ & $\begin{array}{l}0.191 \\
(.399)\end{array}$ & $\begin{array}{r}-0.178 \\
(.301)\end{array}$ & $\begin{array}{l}-0.520 \\
(.001)^{\mathrm{a}}\end{array}$ \\
\hline Change in industry cash flow & $\begin{array}{l}0.043 \\
(.967)\end{array}$ & $\begin{array}{r}-0.047 \\
(.786)\end{array}$ & $\begin{array}{l}0.248 \\
(.079)^{\mathrm{c}}\end{array}$ & $\begin{array}{l}0.050 \\
(.720)\end{array}$ \\
\hline $\begin{array}{l}\text { Industry sensitivity to aggregate } \\
\text { industrial production }\end{array}$ & $\begin{array}{r}-0.009 \\
(.266)\end{array}$ & $\begin{array}{l}0.000 \\
(.995)\end{array}$ & $\begin{array}{r}-0.009 \\
(.174)\end{array}$ & $\begin{array}{r}-0.008 \\
(.184)\end{array}$ \\
\hline $\begin{array}{l}\text { Lagged productivity of industry } \\
\text { segment (TFP) }\end{array}$ & $\begin{array}{l}0.155 \\
(.037)^{\mathrm{a}}\end{array}$ & $\begin{array}{l}0.234 \\
(.006)^{\mathrm{a}}\end{array}$ & $\begin{array}{l}0.237 \\
(.000)^{\mathrm{a}}\end{array}$ & $\begin{array}{l}0.167 \\
(.004)^{\mathrm{a}}\end{array}$ \\
\hline $\begin{array}{l}\text { Segment } \mathrm{TFP} * \text { change in industry } \\
\text { shipments }\end{array}$ & $\begin{array}{l}0.451 \\
(.884)\end{array}$ & $\begin{array}{l}-0.906 \\
(.362)\end{array}$ & $\begin{array}{r}-0.461 \\
(.506)\end{array}$ & $\begin{array}{l}0.891 \\
(.080)^{\mathrm{c}}\end{array}$ \\
\hline $\begin{array}{l}\ln (\text { lagged firm size }) \\
\quad(\text { coefficient*10,000,000) }\end{array}$ & $\begin{array}{l}3.470 \\
(.001)^{\mathrm{a}}\end{array}$ & $\begin{array}{l}0.643 \\
(.044)^{b}\end{array}$ & $\begin{array}{l}0.163 \\
(.000)^{\mathrm{a}}\end{array}$ & $\begin{array}{l}0.158 \\
(.049)^{\mathrm{b}}\end{array}$ \\
\hline $\begin{array}{l}\text { Average number of plants per } \\
\text { industry segment }\end{array}$ & & $\begin{array}{l}0.026 \\
(.000)^{\mathrm{a}}\end{array}$ & $\begin{array}{l}0.095 \\
(.000)^{\mathrm{a}}\end{array}$ & $\begin{array}{l}0.072 \\
(.000)^{\mathrm{a}}\end{array}$ \\
\hline Total Firm Years & 75,691 & 21,714 & 36,677 & 37,010 \\
\hline Chi - Squared Statistic & 28.39 & 89.25 & 181.55 & 119.28 \\
\hline Significance Level (p-value) & $<1 \%$ & $<1 \%$ & $<1 \%$ & $<1 \%$ \\
\hline
\end{tabular}


Table VII

Summary Statistics for Change in Productivity for Assets Sold or Merged

Table presents the change in productivity, industry and year adjusted, for three years surrounding asset sales mergers, or full firm sales (year -1 to year +2 ). Values represent sample means for transactions between buyers and sellers. (Standard error of the mean in parentheses.)

\begin{tabular}{lccc}
\hline \multicolumn{3}{c}{ Panel A: Partial Firm Sales } \\
\hline \multicolumn{3}{c}{ Selling Firm Characteristics } \\
Multi-division Firm & Single Segment Firm \\
& Main Division & Peripheral Division \\
\hline Buying Firm Characteristics & & & \\
Multi-division buyer adds to: & & & \\
Main division & $0.106^{\text {a }}$ & $0.147^{\text {a }}$ & 0.083 \\
& $(0.044)$ & $(0.040)^{\text {a }}$ & $(0.119)$ \\
Peripheral division & -0.019 & $0.131^{\text {a }}$ & 0.141 \\
& $(0.039)$ & $(0.031)$ & $(0.134)$ \\
Single segment buyer & 0.048 & $0.175^{\text {a }}$ & $0.121^{*}$ \\
& $(0.078)$ & $(0.071)$ & $(0.082)$ \\
\hline
\end{tabular}

Panel B: Full Firm Sales and Mergers

Selling Firm Characteristics

Multi-division Firm

Main Division Peripheral Division
Single Segment Firm with 1 plant with $>1$ plant

\section{Buying Firm Characteristics}

Multi-division buyer adds to:

$\begin{array}{cccrr}\text { Main division } & 0.134^{\mathrm{a}} & 0.315^{\mathrm{a}} & -0.009 & 0.018 \\ & (0.046) & (0.114) & (0.047) & (0.052) \\ \text { Peripheral division } & -0.022 & 0.043 & -0.021 & -0.045 \\ & (0.033) & (0.039) & (0.048) & (0.061) \\ \text { Single segment buyer } & -0.198^{\mathrm{b}} & -0.193^{*} & 0.079 & -0.018 \\ & (0.094) & (0.133) & (0.050) & (0.066)\end{array}$

a, b, c : Significantly different from 0 at the $1 \%, 5 \%$, and $10 \%$ levels, respectively, using a 2-tailed test for a difference in the mean from zero.

* less than 50 observations 


\section{Table VIII}

\section{Change in Productivity Based on Selling Firm Charactistics}

Regressions test the effects of transaction and selling firm characteristics on the change in plant productivity over a threeyear horizon from the year prior to the asset sale or merger (year -1) to the end of the second year (year+2) after the transaction. Total Factor Productivity (TFP) is calculated using a translog production function. The change in productivity is industry and year-adjusted. We estimate the regressions using ordinary least squares and with firm-level fixed effects. Significance tests are conducted using heteroskedasticity-consistent standard errors. (p-values are in parentheses.)

\begin{tabular}{|c|c|c|c|}
\hline \multicolumn{4}{|c|}{ Dependent Variable: Change in Productivity Year -1 to +2} \\
\hline Variable & \multicolumn{2}{|c|}{ All Plants (transaction and no-transaction) } & $\begin{array}{c}\text { Just Plants } \\
\text { that are sold } \\
\end{array}$ \\
\hline \multicolumn{4}{|l|}{ Transaction Characteristics } \\
\hline $\begin{array}{l}\text { Partial or full divisional asset sale } \\
\text { indicator variable }\end{array}$ & $\begin{array}{l}0.100 \\
(.000)^{\mathrm{a}}\end{array}$ & $\begin{array}{l}0.102 \\
(.000)^{\mathrm{a}}\end{array}$ & $\begin{array}{l}0.062 \\
(.023)^{\mathrm{b}}\end{array}$ \\
\hline $\begin{array}{l}\text { Firm selloff / merger indicator } \\
\text { variable }\end{array}$ & $\begin{array}{l}0.014 \\
(.553)\end{array}$ & $\begin{array}{l}0.002 \\
(.938)\end{array}$ & \\
\hline $\begin{array}{c}\text { Asset sale in main division } \\
\text { indicator variable }\end{array}$ & $\begin{array}{l}-0.071 \\
(.001)^{\mathrm{a}}\end{array}$ & $\begin{array}{l}-0.057 \\
(.012)^{b}\end{array}$ & $\begin{array}{l}-0.099 \\
(.000)^{\mathrm{a}}\end{array}$ \\
\hline $\begin{array}{l}\text { Asset sale by single-segment firm } \\
\text { indicator variable }\end{array}$ & $\begin{array}{l}-0.049 \\
(.225)\end{array}$ & $\begin{array}{r}-0.031 \\
(.496)\end{array}$ & $\begin{array}{l}-0.120 \\
(.004)^{\mathrm{a}}\end{array}$ \\
\hline $\begin{array}{l}\text { Firm selloff: plant in main division } \\
\text { indicator variable }\end{array}$ & $\begin{array}{l}0.005 \\
(.866)\end{array}$ & $\begin{array}{l}0.015 \\
(.606)\end{array}$ & $\begin{array}{r}-0.036 \\
(.215)\end{array}$ \\
\hline $\begin{array}{l}\text { Firm selloff: plant of single-segment } \\
\text { firm indicator variable }\end{array}$ & $\begin{array}{r}-0.008 \\
(.780)\end{array}$ & $\begin{array}{r}-0.001 \\
(.984)\end{array}$ & $\begin{array}{l}-0.102 \\
(.000)^{\mathrm{a}}\end{array}$ \\
\hline \multicolumn{4}{|l|}{ Firm Characteristics } \\
\hline $\begin{array}{l}\ln (\text { lagged firm size }) \\
\quad(\text { coefficient } * 10,000,000)\end{array}$ & $\begin{array}{l}0.001 \\
(.470)\end{array}$ & $\begin{array}{r}-0.013 \\
(.131)\end{array}$ & $\begin{array}{l}0.041 \\
(.100)^{\mathrm{a}}\end{array}$ \\
\hline Number of three-digit industries & $\begin{array}{l}-0.001 \\
(.059)\end{array}$ & $\begin{array}{r}-0.001 \\
(.268)\end{array}$ & $\begin{array}{l}-0.004 \\
(.016)^{\mathrm{a}}\end{array}$ \\
\hline Number of plants of selling firm & $\begin{array}{l}0.000 \\
(.240)\end{array}$ & $\begin{array}{l}0.000 \\
(.280)\end{array}$ & $\begin{array}{l}0.001 \\
(.022)^{\mathrm{a}}\end{array}$ \\
\hline $\begin{array}{l}\text { Indicator variable if plant is part of } \\
\text { a multiple-division firm }\end{array}$ & $\begin{array}{l}0.029 \\
(.000)^{\mathrm{a}}\end{array}$ & $\begin{array}{l}0.028 \\
(.002)^{\mathrm{a}}\end{array}$ & \\
\hline $\begin{array}{l}\text { Indicator variable if plant is part of } \\
\text { a main division }\end{array}$ & $\begin{array}{l}-0.008 \\
(.030)^{b}\end{array}$ & $\begin{array}{l}-0.014 \\
(.000)^{\mathrm{a}}\end{array}$ & \\
\hline $\begin{array}{l}\text { Lagged productivity (year }-1 \text { ) } \\
\text { of selling firm }\end{array}$ & & & $\begin{array}{l}-0.369 \\
(.000)^{b}\end{array}$ \\
\hline Constant & $\begin{array}{l}-0.019 \\
(.000)^{b}\end{array}$ & $\begin{array}{l}-0.015 \\
(.036)^{b}\end{array}$ & $\begin{array}{l}0.141 \\
(.000)^{\mathrm{a}}\end{array}$ \\
\hline Total Plant Years & 255,470 & 255,470 & 14,592 \\
\hline F-test signficance for all coefficients & 10.10 & 7.63 & 34.18 \\
\hline Significance Level (p-value) & $<1 \%$ & $<1 \%$ & $<1 \%$ \\
\hline
\end{tabular}

a, b, c : Significantly different from 0 at the $1 \%, 5 \%$, and $10 \%$ levels, respectively, using a 2 -tailed test. 
Table IX

\section{Economic Significance of Seller Regression Results}

Predicted change in plant-level productivity over a three year horizon varying seller initial productivity initial productivity, from the 25th to the 75th percentiles. For multiple-segment selling firms, we compute predicted changes in productivity using the coefficients estimates from Table VII, column 3. For singlesegment firms, we compute predicted changes use coefficients from regressions for single-segment firms, with one plant and greater than one plant respectively. We hold all variables except the buyer initial relative productivity at their sample medians

\begin{tabular}{lccc}
\hline Initial Relative Productivity at the: & 25th & 50 th & 75th \\
& Percentile & Percentile & Percentile \\
\hline
\end{tabular}

\section{Conglomerate Firms:}

Partial division sale

Seller sells from its main division

0.129

0.021

$-0.079$

Seller sells from its peripheral division(s)

0.169

0.091

0.005

Full firm sale or merger

Seller plants in its main division

0.130

0.022

$-0.079$

Seller plants in its peripheral division(s)

0.107

0.028

$-0.056$

\section{Single Segment Firms:}

Partial division sale

0.172

0.071

$-0.041$

Full firm sale or merger

Seller has only 1 plant

0.445

0.201

$-0.061$

Seller has multiple plants

0.092

$-0.009$

$-0.121$ 


\section{Table X}

\section{Change in Productivity Based on Buying Firm Charactistics}

Regressions test the effects of transaction and buying firm characteristics on the change in plant productivity over a threeyear horizon from the year prior to the asset sale or merger (year -1) to the end of the second year (year+2) after the transaction. Total Factor Productivity (TFP) is calculated using a translog production function. The change in productivity is industry and year-adjusted. We estimate the regressions using ordinary least squares and with firm-level fixed effects. Significance tests are conducted using heteroskedasticity-consistent standard errors. (p-values are in parentheses.)

\section{Dependent Variable: Change in Productivity Year -1 to +2}

\begin{tabular}{|c|c|c|c|}
\hline Variable & $\begin{array}{l}\text { All Plants (transactior } \\
\qquad(\mathrm{OLS})\end{array}$ & $\begin{array}{r}\text { no-transaction) } \\
\text { (fixed effects) } \\
\end{array}$ & $\begin{array}{c}\text { Just Plants } \\
\text { that are bought } \\
\end{array}$ \\
\hline \multicolumn{4}{|l|}{ Transaction Characteristics } \\
\hline $\begin{array}{l}\text { Partial or full divisional asset sale } \\
\text { indicator variable }\end{array}$ & $\begin{array}{l}0.040 \\
(.019)^{b}\end{array}$ & $\begin{array}{l}0.047 \\
(.002)^{\mathrm{a}}\end{array}$ & $\begin{array}{l}0.037 \\
(.055)^{\mathrm{c}}\end{array}$ \\
\hline $\begin{array}{l}\text { Firm selloff / merger indicator } \\
\text { variable }\end{array}$ & $\begin{array}{r}-0.020 \\
(.159)\end{array}$ & $\begin{array}{l}-0.023 \\
(.090)^{c}\end{array}$ & \\
\hline $\begin{array}{l}\text { Asset purchase in main division } \\
\text { indicator variable }\end{array}$ & $\begin{array}{l}0.069 \\
(.023)^{\mathrm{b}}\end{array}$ & $\begin{array}{l}0.065 \\
(.013)^{\mathrm{b}}\end{array}$ & $\begin{array}{l}0.026 \\
(.346)\end{array}$ \\
\hline $\begin{array}{l}\text { Asset purchase by single-segment firm } \\
\text { indicator variable }\end{array}$ & $\begin{array}{l}0.030 \\
(.437)\end{array}$ & $\begin{array}{l}0.048 \\
(.211)\end{array}$ & $\begin{array}{l}0.054 \\
(.131)\end{array}$ \\
\hline $\begin{array}{l}\text { Firm selloff: purchase in main division } \\
\text { indicator variable }\end{array}$ & $\begin{array}{l}0.078 \\
(.004)^{\mathrm{a}}\end{array}$ & $\begin{array}{l}0.089 \\
(.001)^{\mathrm{a}}\end{array}$ & $\begin{array}{l}0.056 \\
(.024)^{b}\end{array}$ \\
\hline $\begin{array}{l}\text { Firm selloff: purchase by single-segment } \\
\text { firm indicator variable }\end{array}$ & $\begin{array}{r}-0.014 \\
(.664)\end{array}$ & $\begin{array}{r}-0.006 \\
(.864)\end{array}$ & $\begin{array}{l}0.002 \\
(.936)\end{array}$ \\
\hline \multicolumn{4}{|l|}{ Firm Characteristics } \\
\hline $\begin{array}{l}\ln (\text { lagged firm size }) \\
\quad(\text { coefficient*10,000,000) }\end{array}$ & $\begin{array}{l}0.001 \\
(.490)\end{array}$ & $\begin{array}{l}-0.024 \\
(.012)^{b}\end{array}$ & $\begin{array}{l}0.027 \\
(.097)^{\mathrm{c}}\end{array}$ \\
\hline Number of three-digit industries & $\begin{array}{l}0.000 \\
(.190)\end{array}$ & $\begin{array}{r}-0.001 \\
(.398)\end{array}$ & $\begin{array}{l}0.002 \\
(.233)\end{array}$ \\
\hline Number of plants of buying firm & $\begin{array}{l}0.000 \\
(.555)\end{array}$ & $\begin{array}{l}0.000 \\
(.749)\end{array}$ & $\begin{array}{l}-0.001 \\
(.005)^{\mathrm{a}}\end{array}$ \\
\hline $\begin{array}{c}\text { Indicator variable if buyer is } \\
\text { a multiple-division firm }\end{array}$ & $\begin{array}{l}0.020 \\
(.000)^{\mathrm{a}}\end{array}$ & $\begin{array}{l}0.013 \\
(.128)\end{array}$ & \\
\hline $\begin{array}{l}\text { Indicator variable if plant is } \\
\text { in a main division }\end{array}$ & $\begin{array}{l}-0.006 \\
(.065)^{c}\end{array}$ & $\begin{array}{l}-0.012 \\
(.001)^{\mathrm{a}}\end{array}$ & \\
\hline $\begin{array}{l}\text { Lagged productivity (year -1) of buying } \\
\text { firm - productivity of plants purchased }\end{array}$ & & & $\begin{array}{l}0.396 \\
(.000)^{\mathrm{b}}\end{array}$ \\
\hline Constant & $\begin{array}{l}-0.012 \\
(.005)^{\mathrm{a}}\end{array}$ & $\begin{array}{l}0.004 \\
(.591)\end{array}$ & $\begin{array}{l}-0.057 \\
(.001)^{\mathrm{a}}\end{array}$ \\
\hline Total Plant Years & 250,574 & 250,574 & 11,718 \\
\hline F-test: signficance for all coefficients & 9.06 & 6.86 & 169.77 \\
\hline Significance Level (p-value) & $<1 \%$ & $<1 \%$ & $<1 \%$ \\
\hline
\end{tabular}

a, b, c : Significantly different from 0 at the $1 \%, 5 \%$, and $10 \%$ levels, respectively, using a 2 -tailed test. 


\section{Table XI}

\section{Economic Significance of Buyer Regression Results}

Predicted change in plant-level productivity over a three year horizon varying buyer initial productivity less initial productivity of plants sold, from the 25 th to the 75 th percentiles. We compute these predicted changes in productivity using the coefficients estimates from Table X, column 3. We hold all variables except the buyer initial relative productivity at their sample medians

Predicted change in productivity of plants transacted using coefficient estimates from Table X, column 3: Variables taken at the respective sample medians.

Initial Relative Productivity at the:

\begin{tabular}{ccc}
\hline 25th & 50th & 75th \\
Percentile & Percentile & Percentile \\
\hline
\end{tabular}

\section{Conglomerate Firms:}

Partial division sale

Buyer adds to its main division

$-0.122$

0.113

0.336

Buyer adds to its peripheral division

$-0.173$

0.055

0.285

Full firm sale or merger

Buyer adds to its main division

$-0.129$

0.107

0.330

Buyer adds to its peripheral division

$-0.209$

0.018

0.248

Single Segment Firms:

Buyer of a partial division sale

Buyer of a full firm sale
$-0.118$

0.114

0.366

$-0.177$

0.055

0.307 
Figure I

Asset Sales and Mergers

$\%$ of Assets Transacted

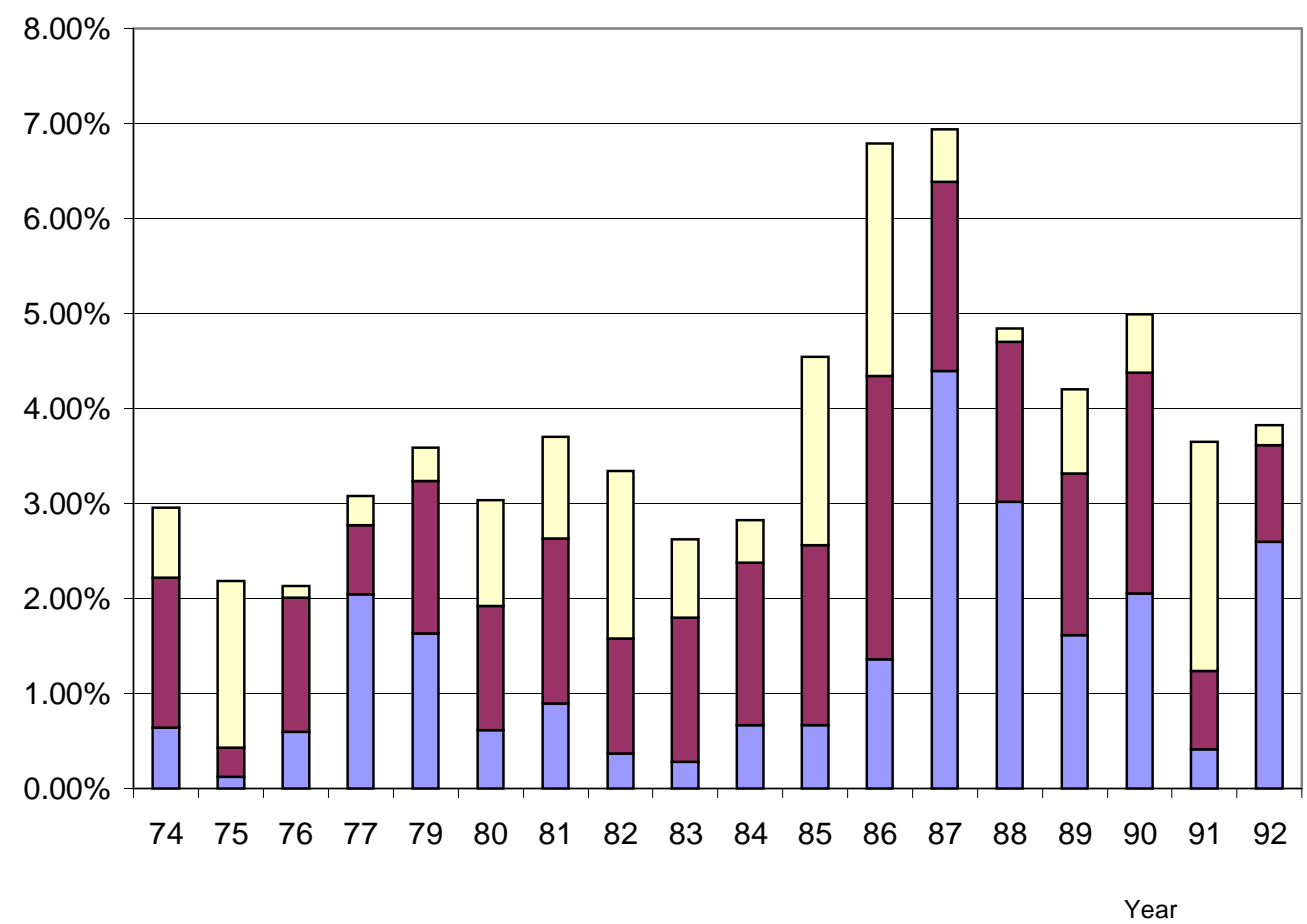

$\square \%$ in Industries in Decline

口\% Unclassified

$\square \%$ Sold in Industries in Expansion 
Figure II

Total Reallocations by Industries in Decline \& Expansion

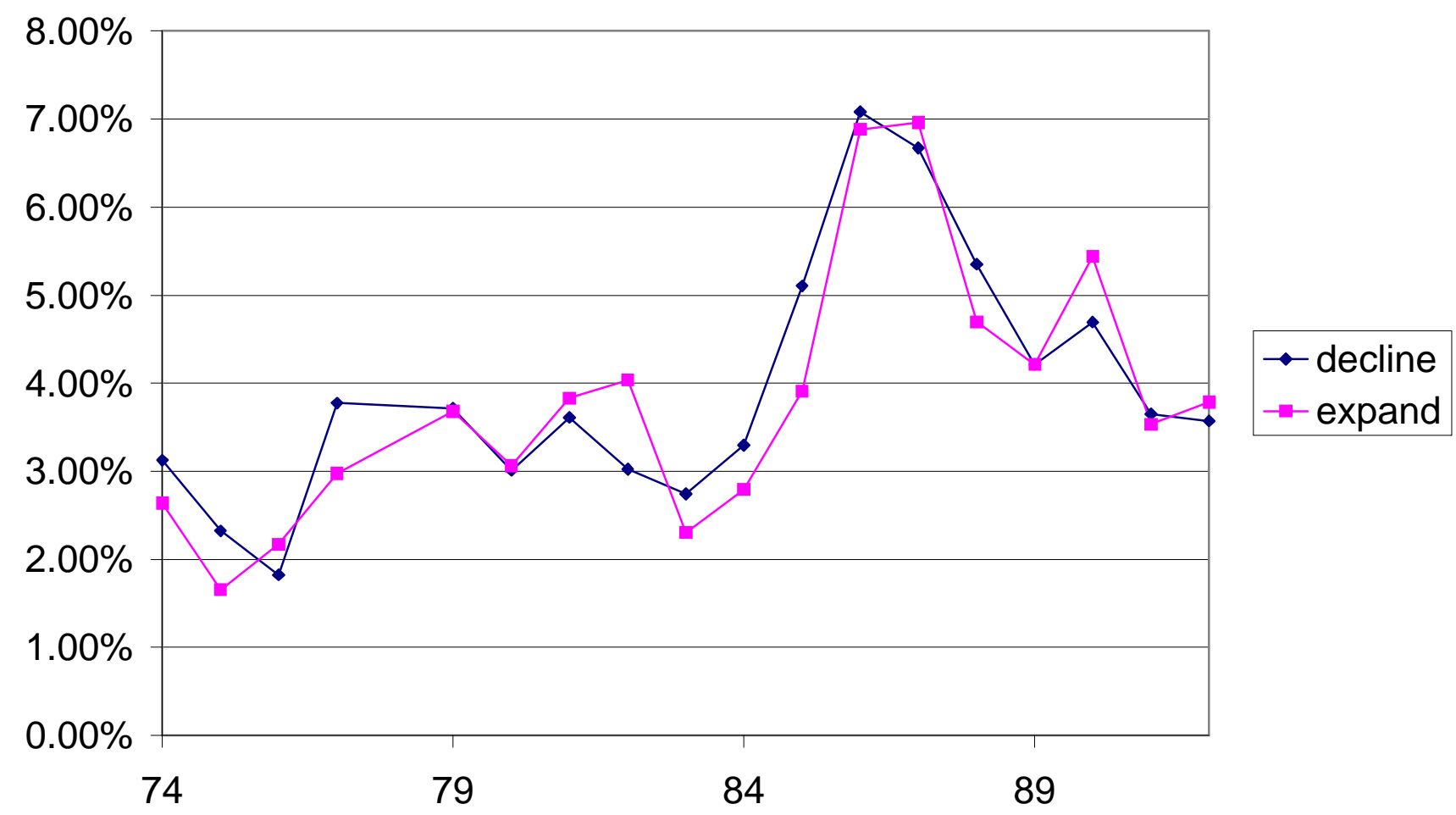


Figure III

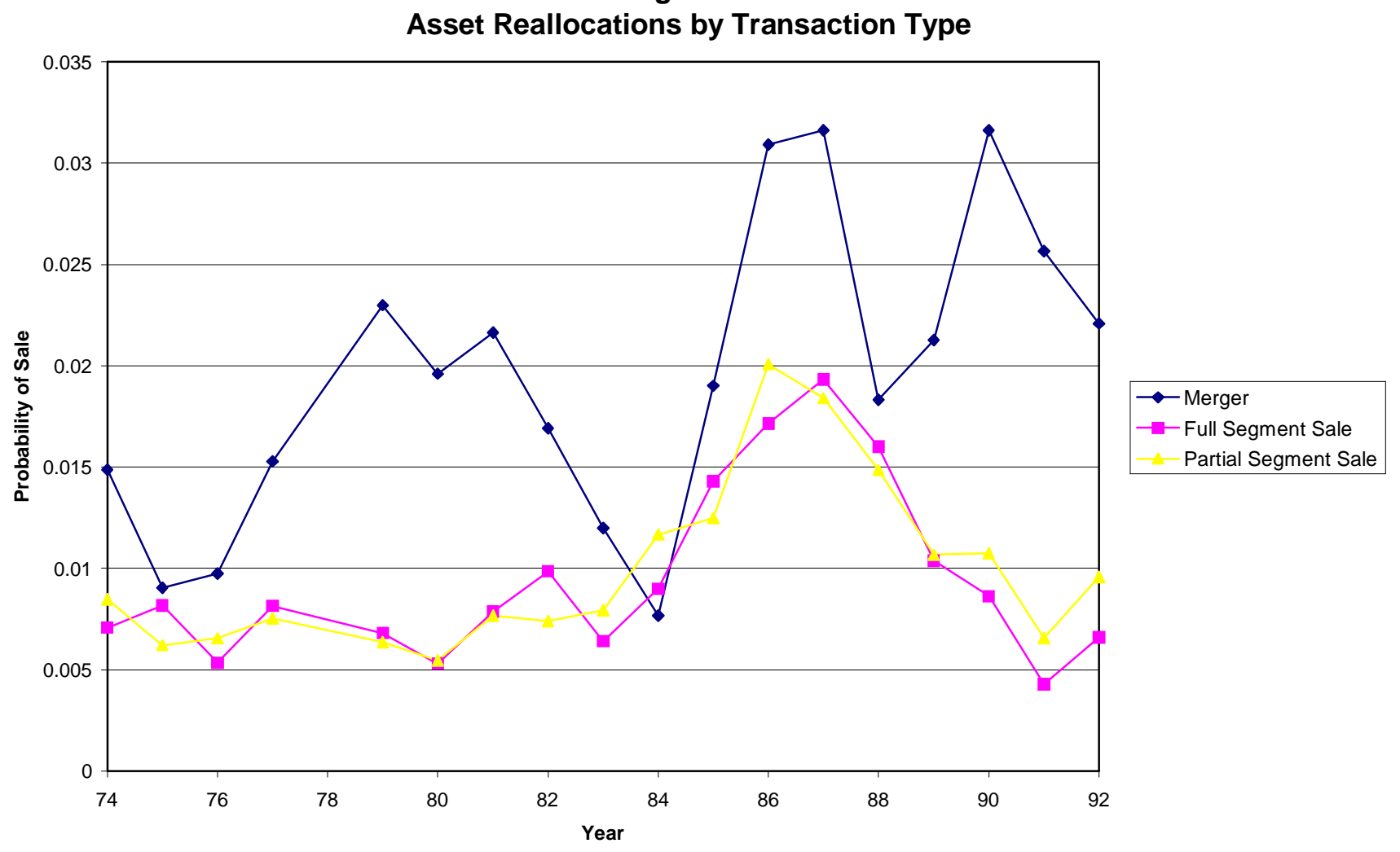


Figure IV

Probablility of an Asset Sale

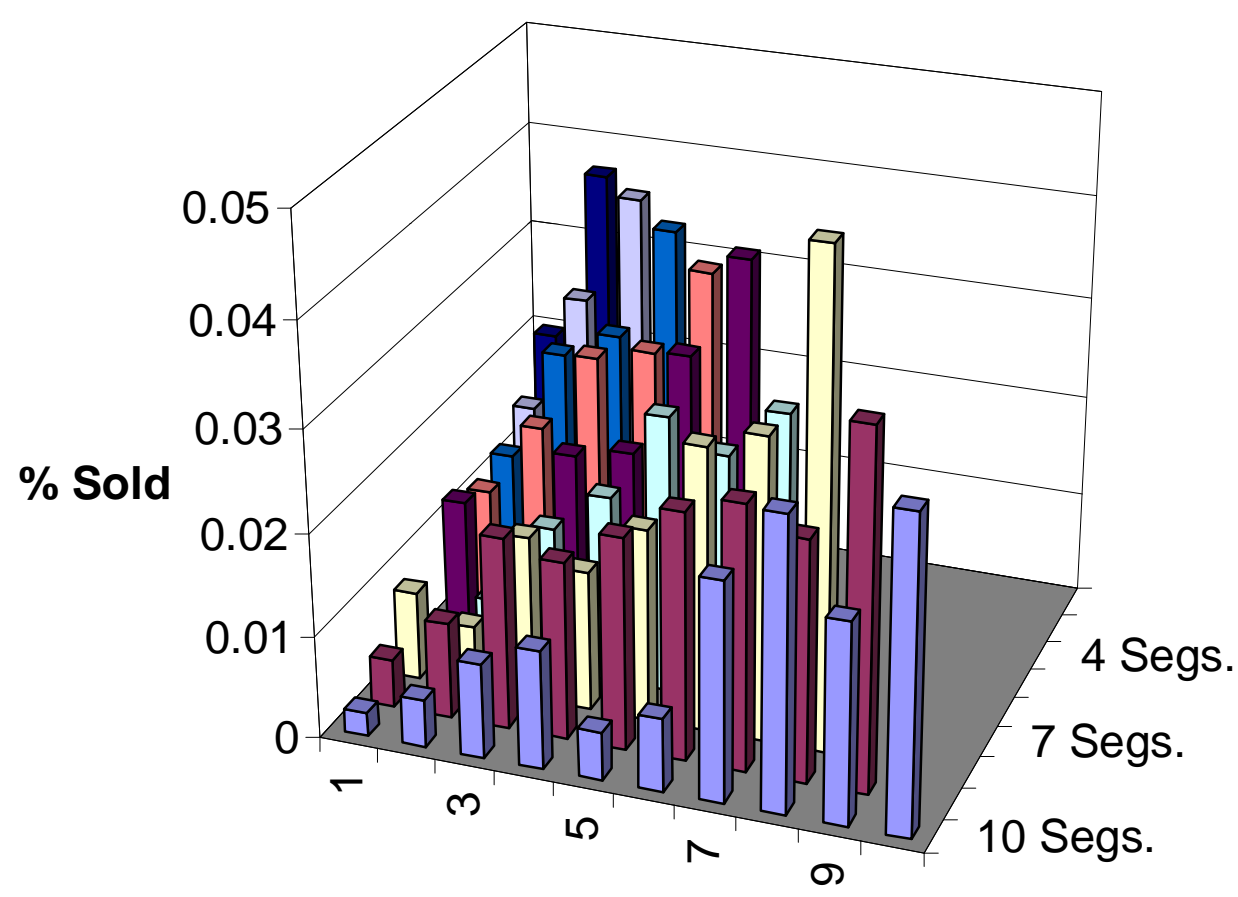

$\square 10$ Segs.

$\square 9$ Segs.

$\square 8$ Segs.

$\square 7$ Segs.

$\square 6$ Segs.

$\square 5$ Segs.

$\square 4$ Segs.

$\square 3$ Segs.

$\square 2$ Segs.

Segment Number 


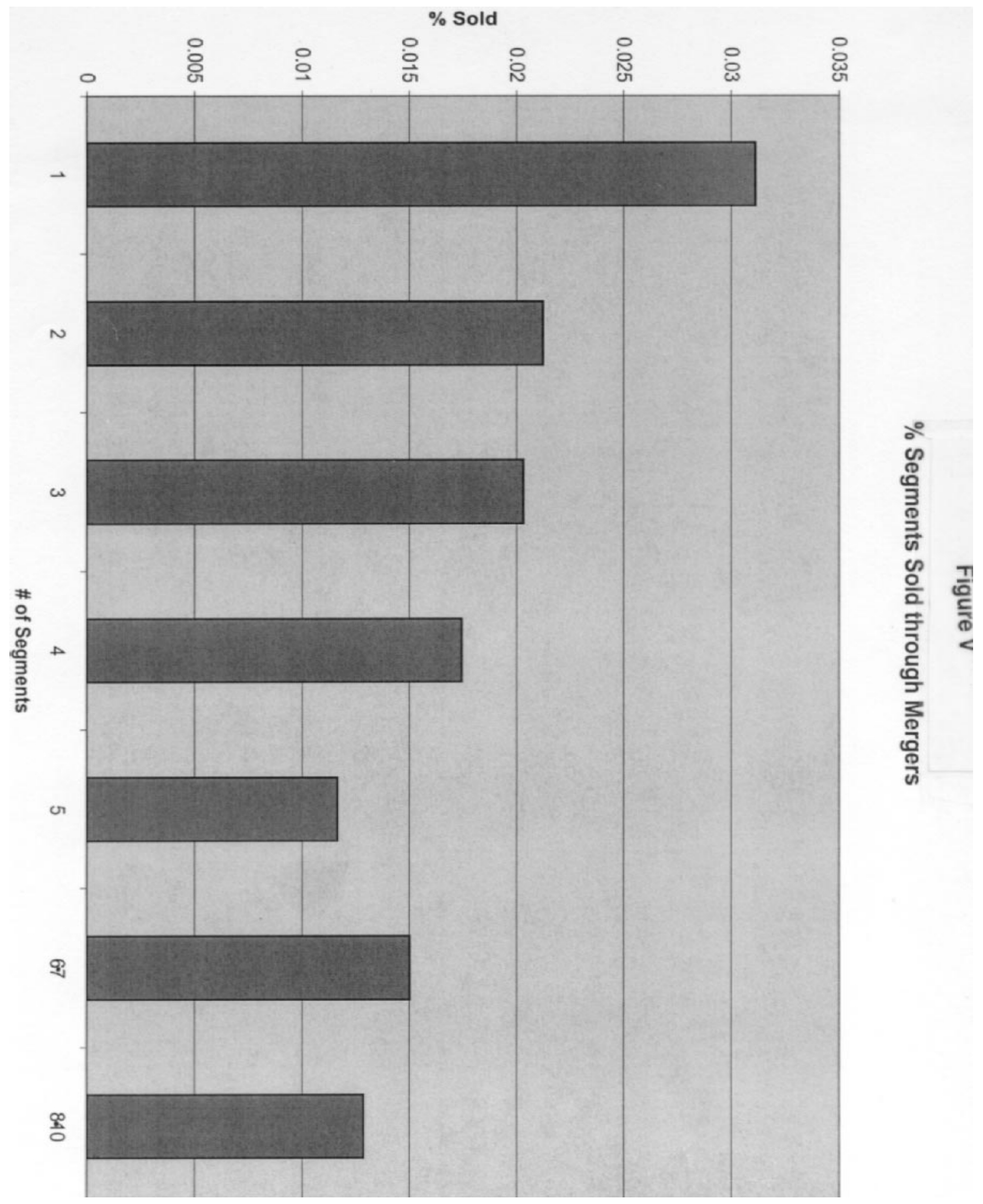

Figure 1: 